University of Rhode Island

DigitalCommons@URI

Open Access Dissertations

2016

\title{
A Multidisciplinary Study on the Crustal Nature of Volcanic Conduits and Magma Reservoirs
}

Ashton F. Flinders

University of Rhode Island, andrealphus@gmail.com

Follow this and additional works at: https://digitalcommons.uri.edu/oa_diss

\section{Recommended Citation}

Flinders, Ashton F., "A Multidisciplinary Study on the Crustal Nature of Volcanic Conduits and Magma Reservoirs" (2016). Open Access Dissertations. Paper 467.

https://digitalcommons.uri.edu/oa_diss/467

This Dissertation is brought to you for free and open access by DigitalCommons@URI. It has been accepted for inclusion in Open Access Dissertations by an authorized administrator of DigitalCommons@URI. For more information, please contact digitalcommons-group@uri.edu. 
A MULTIDISCIPLINARY STUDY ON THE CRUSTAL NATURE OF VOLCANIC CONDUITS AND MAGMA RESERVOIRS

BY

ASHTON F. FLINDERS

A DISSERTATION SUBMITTED IN PARTIAL FULFILLMENT OF THE

REQUIREMENT FOR THE DEGREE OF

DOCTOR OF PHILOSOPHY

IN

OCEANOGRAPHY

UNIVERSITY OF RHODE ISLAND

2016 
DOCTOR OF PHILOSOPHY DISSERTATION

OF

ASHTON F. FLINDERS

APPROVED:

Dissertation Committee:

Major Professor

Yang Shen

Co-Major Professor

Chris Roman

Steve Carey

Gopu Potty

Nasser H. Zawia

DEAN OF THE GRADUATE SCHOOL

UNIVERSITY OF RHODE ISLAND

2016 


\begin{abstract}
Volcanic settings vary widely not only in their eruptive style and products, but in the manner magma travels from deep sources to individual eruptive centers. Imaging these pathways, and their associated crustal reservoirs, provides unique and unprecedented views into these environments. Imaging techniques are varied with the strength of the technique often based on data availability. As such, we focus on two methods-gravity and seismic-in two different settings, each with its own unique volcanic environments, crustal structures, and associated data resources. The first, the Hawaiian Islands, are the most geologically studied hot-spot islands in the world, yet the only large-scale compilation of marine and land gravity data is more than 45 years old. We present a new chain-wide gravity compilation allowing us to locate current and former volcanic centers, major rift zones, a previously suggested volcano, and show that volcanoes along the chain are composed of a small proportion of intrusive material $(<30 \%$ by volume). At the second area, the arc-volcanism of southern Washington, we used ambient seismic noise methods to constrain the crustal pathways of deep-sourced melt to the surface. We image two zones of reduced velocity, one of which correlates with a proposed extensive zone of mid-crustal partial melt which likely supplies evolved magmas to the surrounding volcanoes and vents, including Mounts St. Helens and Adams.
\end{abstract}




\section{ACKNOWLEDGMENTS}

I would like to thank the numerous faculty, staff, and students at the University of Hawaii, the University of New Hampshire, and the University of Rhode Island who have contributed their insight, expertise, and support along my academic journey. This dissertation would not have possible without the leniency of my two advisors, Yang Shen and Chris Roman, who allowed me to follow those pursuits I found interesting. Yang Shen's continual guidance throughout my research at GSO, particularly related to seismic tomography, is something I hope to one day pass on to my own students. Similarly, Steve Carey, will always be the volcanologist I strive to be, even if I'm really just a geophysicist playing at volcanoes.

My academic pursuit is, and will continue to be, driven by wish to make my mother proud. Through all aspects of her life, including academic, she taught me what true dedication, perseverance, and strength are. While I am sad she will not be here to see me finish the path she saw me start on, I know the joy it would have brought her. 


\section{PREFACE}

The following dissertation examines and characterizes crustal magmaticpathways at two unique volcanic settings; the hot-spot volcanism of the Hawaiian Islands, and the arc-volcanism of southern Washington. The dissertation is written in manuscript format, comprised of the two following manuscripts:

Manuscript one, "Intrusive dike-complexes, cumulate cores and the extrusive growth of Hawaiian volcanoes" entailed the first large-scale compilation of marine and land gravity data for the Hawaiian Islands in more than 45 years. This new chain-wide gravity compilation, and subsequent geophysical inversions, permitted the generation of 3D views of the dense, intrusive complexes and olivine-rich cumulate cores within individual volcanoes and rift zones. This manuscript was published in Geophysical Research Letters, July 2013.

Manuscript two, "Seismic evidence for multi-level magmatic plumbing systems in the crust beneath southwest Washington" is a high-resolution model of the crustal shear-wave velocity underneath southwest Washington. While regional volcanism in general is driven by subduction of the Juan de Fuca slab beneath the North American continent, volcanic pathways in the crust are shown to be complex and varied. This manuscript is prepared, with submission to Nature expected in May, 2016. 
TABLE OF CONTENTS

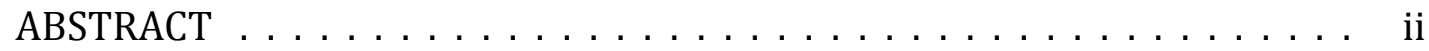

ACKNOWLEDGMENTS . . . . . . . . . . . . . . . . . iii

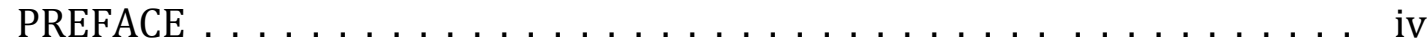

TABLE OF CONTENTS $\ldots \ldots \ldots \ldots \ldots \ldots \ldots \ldots$

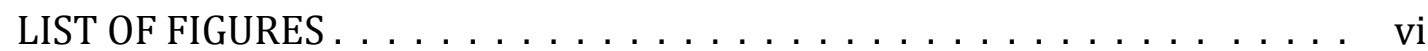

LIST OF TABLES . . . . . . . . . . . . . . . . . . . . vii

CHAPTER 1 Intrusive dike-complexes, cumulate cores and the 1 extrusive growth of Hawaiian volcanoes $\ldots \ldots \ldots \ldots \ldots$

CHAPTER 2 Seismic evidence for multi-level magmatic plumbing systems in the crust beneath southwest Washington . . . . . . . . . . 21

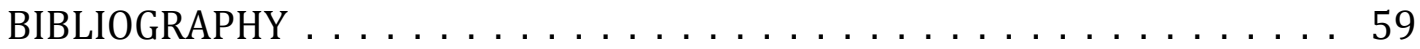




\section{LIST OF FIGURES}

FIGURE

PAGE

Figure 1.1 Free-air gravity anomalies of the Hawaiian Islands . . . . . . . . 16

Figure 1.2 Bouguer gravity anomalies of the Hawaiian Islands $\ldots . . . . .17$

Figure 1.3 Residual gravity anomalies of the Hawaiian Islands . . . . . . . 18

Figure 1.4 Density isosurfaces from inverted 3D density models . . . . . . . 19

Figure 2.1 Overview of study area $\ldots \ldots \ldots \ldots \ldots$

Figure 2.2 Shear-wave velocity at $8 \mathrm{~km}$ depth $\& 3 \mathrm{D}$ perspective $\ldots . . . .41$

Figure 2.3 Shear-wave velocity at $22 \mathrm{~km}$ depth and $7 \%$ Slow $\mathrm{V}_{\mathrm{s}}$ Isosurface . 43

Figure S2.2 Data processing flow-chart area . . . . . . . . . . . . . 47

Figure S2.3 Tomography flow-chart . . . . . . . . . . . . . . . . . 48

Figure S2.4 Station locations, ray-paths, and stacked distributions of empirical Green's functions . . . . . . . . . . . . . . . . . . . . 49

Figure S2.5 Empirical Green's functions versus distance . . . . . . . . . . . . 50

Figure S2.6 Starting model . . . . . . . . . . . . . . . . . . . . 51

Figure S2.7 Simulation snapshot $\ldots \ldots \ldots \ldots$. . . . . . . . . . . . . . .

Figure S2.8 Phase-delay measurement . . . . . . . . . . . . . . . . . 53

Figure S2.9 Shear wave velocity phase kernels $\ldots \ldots \ldots$. . . . . . . . . . . 54

Figure S2.10 Phase-delay convergence . . . . . . . . . . . . . . . 55

Figure S2.11 Convergence statistics . . . . . . . . . . . . . . 56

Figure S2.12 Checkerboard tests . . . . . . . . . . . . . . . . 57

Figure $\mathrm{S} 2.13$ Synthetic tests $\ldots \ldots \ldots \ldots \ldots \ldots$. . . . . . . . . . . . . . . . . . 


\section{LIST OF TABLES}

TABLE

PAGE

Table 1.1 Volcanic features and their cumulate cores/intrusive complexes . 20

Table S2.1 Station Locations and Start/End Times. . . . . . . . . . . . . . . 44 
MANUSCRIPT 1

Intrusive dike-complexes, cumulate cores and the extrusive growth of Hawaiian volcanoes

by

Ashton F. Flinders ${ }^{1}$, Garret Ito ${ }^{2}$, Michael O. Garcia², John M. Sinton², Jim Kauahikaua $^{3}$, Brian Taylor ${ }^{2}$

Published in Geophysical Research Letters, July 2013

${ }^{1}$ Graduate School of Oceanography, University of Rhode Island, Narragansett, RI 02882

${ }^{2}$ Department of Geology and Geophysics, University of Hawaii at Manoa, Honolulu, HI 96822

${ }^{3}$ United States Geological Survey, Hawaii National Park, HI, 96718 


\section{Abstract}

The Hawaiian Islands are the most geologically studied hot-spot islands in the world, yet surprisingly, the only large scale compilation of marine and land gravity data is more than 45 years old. Early surveys served as reconnaissance studies only and detailed analyses of the crustal-density structure have been limited. Here, we present a new chain-wide gravity compilation that incorporates historical island surveys, recently published work on the islands of Hawai'i, Kaua'i, and Ni'ihau, and $>122,000 \mathrm{~km}$ of newly compiled marine gravity data. Positive residual gravity anomalies reflect dense intrusive bodies, allowing us to locate current and former volcanic centers, major rift zones and a previously suggested volcano on Ka'ena Ridge. By inverting the residual gravity data, we generate a 3D view of the dense, intrusive complexes and olivine-rich cumulate cores within individual volcanoes and rift zones. We find that the Hana and Ka'ena ridges are underlain by particularly high-density intrusive material $\left(>2.85 \mathrm{~g} / \mathrm{cm}^{3}\right)$, not observed beneath other Hawaiian rift zones. Contrary to previous estimates, volcanoes along the chain are shown to be composed of a small proportion of intrusive material ( $<30 \%$ by volume), implying that the islands are predominately built extrusively. 


\section{Introduction}

The main Hawaiian Islands evolve from active volcanoes on the southeastern end-Mauna Loa, Kilauea and Lo'ihi-to the eroded remnant of Ni'ihau Volcano $600 \mathrm{~km}$ to the northwest (Fig. 1.4a). Progressive cooling and crystallization of magma in crustal reservoirs and surrounding rift zones produces rocks rich in olivine (cumulates). These cumulate cores define the long-term average zones where magma resided or transited through, prior to surface eruptions or emplacement in shallow intrusions (Kauahikaua et al., 2000). Encompassing the cumulate cores are larger zones of dense, dike-rich, intrusions-intrusive complexes-comprising the magmatic plumbing system feeding each volcano. Density contrasts between these features and encompassing lava flows result in positive residual gravity anomalies (Strange et al., 1965; Kauahikaua et al., 2000; Flinders et al., 2010) and often correlate with fast seismic velocities (Okubo et al., 1997; Park et al., 2009). Here, we invert a new chain-wide compilation of land and marine gravity data to estimate the volumes, average densities, and olivine percentages of intrusive complexes and cumulate cores underlying all known volcanoes throughout the Hawaiian Islands.

\section{Data Reduction}

Our new compilation is composed of 4820 land-based measurements, including historical data (Strange et al., 1965) and data from recent studies of Kaua'i (Flinders et al., 2010) and the island of Hawai'i (Kauahikaua et al., 2000). 
Free-air anomalies (Fig. 1.1) were produced by removing elevation contributions (for land-based data) and the WGS84 ellipsoid. The marine portion of the compilation consists of over $122,000 \mathrm{~km}$ of survey data collected on 140 cruises. The marine data were collected primarily aboard the University of Hawai'i $R / V$ Kilo Moana, supplemented with data from the National Geophysical Data Center and the Japan Agency for Marine-Earth Science and Technology (Fig. 1.1, inset). These data were filtered to eliminate high-frequency noise, due to changes in survey speed and course, and corrected for crossover errors using x2sys, a part of the Generic Mapping Tools (Wessel and Smith, 1991). The standard deviation of the corrected crossings was $2 \mathrm{mGal}$.

Complete Bouguer anomalies were produced by removing the effects of topography/bathymetry using a two-part prism-based terrain correction (Fig. 1.2; Flinders et al., 2010). Within $500 \mathrm{~km}$ of each measurement, the water column was in-filled with submarine crust $\left(2.7 \mathrm{~g} / \mathrm{cm}^{3}\right)$, using a $250 \mathrm{~m}$ digital elevation model (DEM) (www.soest.hawaii.edu/HMRG). The gravitational effects of subaerial mass $\left(2.4 \mathrm{~g} / \mathrm{cm}^{3}\right)$ were removed using DEM's of various spatial resolution, dependent on the distance from the measurement: a $10 \mathrm{~m}$ DEM within $2 \mathrm{~km}$ of the measurement location, $100 \mathrm{~m}$ DEM at distances of 2-20 km and a $500 \mathrm{~m}$ DEM at distances of $20-500 \mathrm{~km}$. Lastly, residual gravity anomalies were produced by removing the long-wavelength signal due to flexural deformation of the lithosphere from island loading (Fig. 1.3), using an 
effective elastic-plate thickness of $30 \mathrm{~km}$ (Fig. 1.2 inset; Watts and Cochran, 1974; Flinders et al., 2010).

\section{3D Inversion}

For inversion, the marine residual gravity data were down-sampled onto a 500m cell-spaced geographic grid, resulting in 42,326 measurements. The cell-spacing used in down- sampling the data was approximately equal to half the minimum one-km horizontal wavelength typically resolvable by the marine data. All land residual gravity data were used. The compiled data set was subdivided into three overlapping geographic regions; Kaua'i/Ni'ihau, O'ahu through Maui, and the island of Hawai'i. Data for each region were inverted to produce 3D models of subsurface density contrast using GRAV3D (GRAV3D, 2007). The subsurface was discretized into a set of 3D voxels, each

with a constant density contrast relative to $2.7 \mathrm{~g} / \mathrm{cm}^{3}$, with voxels spanning $1 \mathrm{~km}$ in the horizontal and varying in the vertical dimension from $500 \mathrm{~m}$ at the surface to $1500 \mathrm{~m}$ at depth. The top of the model space was bound by topography/bathymetry while the model basement, at $20 \mathrm{~km}$ below sea level, encompassed the base of the thickest Hawaiian volcanic crust (13 km) and $7 \mathrm{~km}$ of preexisting oceanic crust (Watts et al., 1985). The density distribution was found by solving an optimization problem of minimizing a model objective function while generating synthetic data that fall within the uncertainty of the observed data (e.g. Li and Oldenburg, 1998; Flinders et al., 2010). Inversions were subject to the constraint that densities be between 
2.0 (wet sand) $-3.3 \mathrm{~g} / \mathrm{cm}^{3}$ (olivine). The three individual inversion models were then merged into one chain-wide model (Fig. 1.4). These inversions provided a low misfit to the residual anomalies, $\approx 2 \mathrm{mGal} r m s$, and inverting the data with a wide range of initial model parameters verified the returned inversion structure.

\section{Intrusive Complexes and Cumulate Cores}

Negative residual gravity (Fig. 1.3) and low crustal densities $(<2.7$ $\mathrm{g} / \mathrm{cm}^{3}$, Fig. 1.4d) are associated with several of the previously mapped debrisavalanche deposits and slumps (Moore et al., 1989), as well as Cretaceous seamounts, the Moloka'i Fracture Zone, and possibly incomplete removal of the flexural signal. Positive residual gravity and high crustal-densities $(>2.7$ $\mathrm{g} / \mathrm{cm}^{3}$ ) are associated with volcanic centers and major rift zones. We interpret the largest of these anomalies to correspond to underlying intrusive complexes-regions of high dike concentration-and cumulate cores (Fig. 1.4a/c). We delineate intrusive complexes by the $2.85 \mathrm{~g} / \mathrm{cm}^{3}$ density isosurface, corresponding to $60 \%$ or more of dikes with a density of 2.95 $\mathrm{g} / \mathrm{cm}^{3}$ (Kilauea $10 \mathrm{wt} \% \mathrm{MgO}$ at $200^{\circ} \mathrm{C} / 1500$ bar-KWare Magma; Wohletz, 1999) in a host extrusive rock of $2.7 \mathrm{~g} / \mathrm{cm}^{3}$. Consistent with this definition, the $2.85 \mathrm{~g} / \mathrm{cm}^{3}$ isosurface lies within the $50-65 \%$ dike concentration used to define the dike-complex zone of Ko'olau volcano by Walker (1986). Cumulate cores were defined by the $3.00 \mathrm{~g} / \mathrm{cm}^{3}$ density isosurface, equivalent to $35 \%$ 
or more olivine $\left(3.2-3.3 \mathrm{~g} / \mathrm{cm}^{3}\right)$ in the intrusive complex density of 2.85 $\mathrm{g} / \mathrm{cm}^{3}$. Approximate uncertainties in the isosurface volumes were found by using the merged density model to forward model simulated residual gravity anomalies at our observation locations. These simulated values were then reinverted, using the original uncertainty matrix, to find a new density model. A comparison of the original density model to the new model corresponded to $\pm 25 \%$ volume uncertainty for both the 2.85 and $3.00 \mathrm{~g} / \mathrm{cm}^{3}$ isosurfaces.

Intrusive complexes are observed beneath all volcanoes, with the maximum intrusive complex volume ranging up to $10,550 \pm 2,600 \mathrm{~km}^{3}$ (Kaua'i; Table 1.1). The olivine contents of the intrusive complexes, estimated as a percentage of the total isosurface volume if the average density was due to only olivine $\left(3.2-3.3 \mathrm{~g} / \mathrm{cm}^{3}\right)$ and intrusive basalt $\left(2.85 \mathrm{~g} / \mathrm{cm}^{3}\right)$, were between $2-25 \%$ (Table 1.1). Differences in the volume of individual intrusive complexes do not vary with their distance along the chain. Instead, the volumes of the intrusive complexes appear to correlate with the volumes of the associated volcanoes (Fig. 1.4b). Volcano volume estimates were taken from Robinson and Eakins (2006), explicitly separating the volume of Hana Ridge from Haleakala Volcano, and from Sinton et al. (2013) for Ka'ena Ridge and Wai'anae Volcano, where a small volume of Ka'ena Ridge $\left(2,525 \mathrm{~km}^{3}\right)$ has been allocated to a separately proposed volcanic center. These correlations suggest an inherent relationship between the volume of erupted lava and the total volume of intrusive material. 
Within the intrusive complexes, dense cumulate cores $\left(>3.0 \mathrm{~g} / \mathrm{cm}^{3}\right)$, were detected under the majority of volcanoes, with volumes ranging from $<10$ $\mathrm{km}^{3}$ (Kilauea) to $1,870 \pm 470 \mathrm{~km}^{3}$ (Kaua'i). Estimated olivine content is greatest in Mauna Loa $(\approx 84 \%)$ and least in Kaho'olawe and Lana'i $(\approx 42 \%)$, averaging $\approx 50 \%$ throughout the chain (Table 1.1 ). Cumulate cores were not present under Loih'i, Hualalai, West Moloka'i, or East Moloka'i volcanoes (Fig. 1.4a). The four largest cumulate cores are spaced sporadically, underlying Kaua'i $\left(1870 \pm 470 \mathrm{~km}^{3}\right)$, Ko'olau $\left(1160 \pm 290 \mathrm{~km}^{3}\right)$, Ni'ihau $\left(300 \pm 80 \mathrm{~km}^{3}\right)$, and Mauna Loa $\left(280 \pm 70 \mathrm{~km}^{3}\right)$, although the volume of Mauna Loa's cumulate core is likely to be underestimated because it is still an active volcano and the cumulate core is presumably still accumulating.

\section{Rift Zones and Unrecognized Volcanoes}

Rift-zone related intrusive complexes are observed beneath the major submarine ridges and tend to be linear features that trace back to individual volcanoes $\left(2.80 \mathrm{~g} / \mathrm{cm}^{3}\right.$ isosurface; Fig. 1.4a). Prominent examples include Kilauea's East Rift Zone, the south-west rift zone of Wai'anae, and the western rift zone of West Moloka'i. However, these rift zones are underlain by distinctly less-dense intrusions than those beneath Hana (Haleakala) and Ka'ena (Wai'anae) Ridges. The rift-zone intrusive complexes along the Hana and Ka'ena ridges are markedly atypical, based on their large volumes, spatial extents and high residual gravity. 
The $120 \mathrm{~km}$-long, $50 \mathrm{~km}$-wide, Hana Ridge is underlain by two dense intrusive bodies (Fig. 1.4a), neither of which is associated with a local bathymetric high. If these features are considered to be part of the Haleakala rift zone, they would constitute the most voluminous, dense, and distal riftzone extension from a volcano throughout the entire chain. Alternatively, these bodies may represent the intrusive complexes of one or two shield volcanoes that did not develop beyond a juvenile stage and were later buried in rift-zone volcanics. Ka'ena Ridge is comparable to Hana Ridge in length and maximum width but contains significant bathymetric relief, including a large (11-km diameter) flat-top cone located near the center of the ridge. Two unique gravity anomalies/intrusive complexes are seen beneath Ka'ena Ridge, a broad eastern anomaly and a more distinct western anomaly, neither of which appears to extend from the Wai'anae rift zone (Fig. 1.4a). Sinton et al. (2013) showed that most of Ka'ena Ridge is chemically, structurally and chronologically distinct from Wai'anae Volcano, and likely represents a precursor volcano to the island of $\mathrm{O}^{\prime} \mathrm{ahu}$, consistent with speculations of Moore et al. (1989). Although the broad eastern gravity anomaly has no associated bathymetric high, it is likely associated with this precursor volcano (Ka'ena Volcano), with its older structure possibly buried by younger Wai'anae flows. The western gravity anomaly is located $3 \mathrm{~km}$ from the center of the 11- km diameter large cone, which is thought to have formed subaerially, given the presence of massive 'a'a flows (Coombs et al., 2004). Geologic samples acquired during a previous ROV dive, appear to be 
geochemically similar to the rest of the ridge (Coombs et al., 2004; Sinton et al., 2013). However, given the distinction between this western gravity anomaly and the broad eastern anomaly (Fig. 1.3, 1.4a), it's association with the nearby large cone, and the relatively sparse geologic sampling of Ka'ena Ridge in general (Sinton et al., 2013), it remains uncertain whether this anomaly represents an extension of the Ka'ena Volcanic system or yet another, unrecognized volcano. We refer to the western feature as Uwapo-Hawaiian for bridge, because it may span the volcanic gap between the islands of Kaua'i and O'ahu. While the modeled intrusive complex beneath Uwapo is small $\left(200 \pm 50 \mathrm{~km}^{3}\right)$, it is roughly half the intrusive-complex volume beneath Hualalai Volcano $\left(450 \pm 110 \mathrm{~km}^{3}\right)$.

\section{Extrusive vs. Intrusive Volcano Building}

The gravity results indicate that individual volcanoes in the Main Hawaiian Islands are composed, on average, of less than $10 \%$ dense intrusive material ( $>2.85 \mathrm{~g} / \mathrm{cm}^{3}$, Table 1.1). An upper bound estimate was made by decreasing the density isosurface for intrusive complexes from $2.85 \mathrm{~g} / \mathrm{cm}^{3}$ to $2.80 \mathrm{~g} / \mathrm{cm}^{3}$, approximately equivalent to changing from a $60 \%$ to $40 \%$ dike concentration, and equal to the cut off between intrusive and extrusive basalt used by Moore (2001). Using this constraint and calculating an intrusive/extrusive ratio across the entire chain, results in a mean increase to only $30 \%$ intrusive material. 
Our estimate of a low intrusive proportion $(10-30 \%)$ is contrary to prior conclusions that the Hawaiian Islands are built through predominately endogenous growth, with previous estimates that intrusions account for 6590\% of the total volume (Francis et al., 1993; Dzurisin et al., 1984). These estimates were based on geologically short-term observations of the active Kilauea Volcano, specifically heat loss over the Kupaianaha lava pond (19861992; Francis et al., 1993) and uplift of Kilauea summit (1956-1983; Dzurisin et al., 1984). Given our conclusion of primarily extrusive growth, the minimization of the chain-wide residual gravity anomaly by a submarine density of $2.7 \mathrm{~g} / \mathrm{cm}^{3}$, and that the majority of each volcano is built during it's tholeiitic shield stage ( $\approx 95 \%$; Clague and Dalrymple, 1987), we conclude that the majority of each volcano ( $>70 \%)$ is likely comprised of submarine extrusive flows formed during the main shield stage. The disparity between previous estimates of extrusive/intrusive ratios and our own may be due to the limited time (yrs) and localization (Kilauea Volcano) of prior observations or a change in the extrusive/intrusive ratio throughout a volcano's growth.

Voluminous extrusive growth also contrasts with the dominantly intrusive nature of continental volcanism, as well as the formation of normal oceanic crust and flood basalt provinces (e.g., Crisp, 1984; White et al., 2006). In continental settings, magma travels greater path lengths through relatively thick and low-density continental crust and thus is more likely to intrude (White et al., 2006). Oceanic flood basalt provinces also require magma to 
penetrate thick crust $(\approx 30 \mathrm{~km}$ or more; Crisp, 1984), additionally having numerous source dikes that span a wide region, leading to a larger intrusive contribution. At mid-ocean ridges, most of the crust is constructed within a vertical accretion zone, proximal to the ridge axis, and the thickness of the intrusive material is controlled by the local temperature structure (Hooft and Detrick, 1993). In contrast, Hawaiian volcanism originates from magma that penetrates a relatively thin crust $<20 \mathrm{~km}$ (oceanic crust plus the volcano; Watts et al., 1985). Additionally, magma travels from depth to the near surface primarily through a single central vertical conduit (Okubo et al., 1997; Kauahikaua et al., 2000) and typically one or two rift zones. While intrusions occur in the central conduit and rift zones, magma retains sufficient mobility such that the major volume of the volcano is formed from lavas erupted well away from these localized sources.

Acknowledgments. Paul Johnson, Nate Sanders and John Smith accommodated numerous data requests. Roman Shekhtman provided support for GRAV3D. Jackie Caplan-Auerbach, David Clague, James Foster, and James Gardner offered comments and suggestions. Reviews by Dan Scheirer, Glyn Williams-Jones, Julia Morgan, and two anonymous reviewers were invaluable. This work benefited from the 2012 AGU Chapman Conference, Hawaiian Volcanoes: From Source to Surface, and we thank it's conveners and all attendees. This work was supported by NSF grant EAR0510482 to M.G. and G.I. This is SOEST contribution 7904 . 


\section{Bibliography}

Clague, D. A., and G. B. Dalrymple (1987), The Hawaiian-Emperor volcanic chain, part I, US Geol. Surv. Prof. Pap. 1350, 5-54.

Crisp, J. A. (1984), Rates of magma emplacement and volcanic output, J. Volcanol. Geotherm. Res., 20, 177-211.

Coombs, M. L., D. A. Clague, G. F. Moore, and B. L. Cousens (2004), Growth and collapse of Waianae Volcano, Hawaii, as revealed by exploration of its submarine flanks, Geochem. Geophys. Geosys., 5(8), 1-30.

Dzurisin, D., R. Y. Koyanagi, and T. T. English (1984), Magma supply and storage at Kilauea volcano, Hawaii, 1956-1983, J. Volcanol. Geotherm. Res., $21(3-4), 177-206$.

Flinders, A. F., G. Ito, and M. O. Garcia (2010), Gravity anomalies of the Northern Hawaiian Islands: Implications on the shield evolutions of Kauai and Niihau, J. Geo-phys. Res., 115(B8), B08412.

Francis, P., C. Oppenheimer, and D. Stevenson (1993), Endogenous growth of persistently active volcanoes, Nature, 366, 554-557.

GRAV3D (2007), A program library for forward modeling and inversion of gravity data over 3D structures. Joint/Cooperative Inversion of Geophysical Data, Ver. 3.0, UBC Geophysical Inversion Facility, Univ. British Columbia, Vancouver.

Hooft, E. E., and R. S. Detrick (1993), The role of density in the accumulation of basaltic metls at mid-ocean ridges, Geophys. Res. Lett., 20(6), 423-426. 
Kauahikaua, J., T. Hildenbrand, and M. Webring (2000), Deep magmatic structures of Hawaiian volcanoes, imaged by three-dimensional gravity models, Geology, 28(10), 883-886.

Li, Y., and D. W. Oldenburg (1998), 3-D inversion of gravity data, Geophysics, $63,109-119$.

Macdonald, G. A., A. T. Abbott, and D. C. Cox (1983), Volcanoes in the Sea: Honolulu, Univ. Hawaii Press, 517.

Moore, J. G., D. A. Clague, R. T. Holcomb, P. W. Lipman, W. R. Normark, and M. E. Torresan (1989), Prodigious submarine landslides on the Hawaiian Ridge, J. Volcanol. Geotherm. Res., 94 (B12), 17465-17484.

Moore, J.G. (2001), Density of basalt core from Hilo drill hole, Hawaii, J. Volcanol.Geotherm. Res., 112 (1-4), 221-230.

Okubo, P. G., H. M. Benz, and B. A. Chouet (1997), Imaging the crustal magma sources beneath Mauna Loa and Kilauea Volcanoes, Hawaii, Geology, 25(10), 867-870.

Park, J., J. K. Morgan, C. A. Zelt, and P. G. Okubo, (2009), Volcano-tectonic implications of 3-D velocity structures derived from joint active and passive source tomography of the island of Hawaii, J. Geophys. Res., 114 (B9), B09301.

Robinson, J. E., and B. W. Eakins (2006), Calculated volumes of individual shield vol- canoes at the young end of the Hawaiian Ridge, J. Volcanol. Geotherm. Res., 151, 309-317. 
Sinton, J. M., D. Eason, M. Tardona, D. Pyle, I. van der Zander, H. Guillou, A. Flinders, D. Clague, and J. Mahoney (2013), Kaena Volcano a precursor volcano of the island of Oahu, Hawaii, Geo. Soc. Amer. Bull., submitted.

Strange, W. E., G. P. Woollard, J. C. and Rose (1965), An analysis of the gravity field over the Hawaiian Islands in terms of crustal structure, Pac. Sci., 19(3), 381-389.

Walker, G. P. (1986), Koolau dike complex, Oahu: intensity and origin of a sheeted-dike complex high in a Hawaiian volcanic edifice, Geology, 14 (4), 310-313.

Watts, A.B., and J. R. Cochran (1974), Gravity anomalies and flexure of the lithosphere along the Hawaiian-Emperor seamount chain, Geophys. J. Royal Astr. Soc., 38(1), 119-141.

Watts, A. B., U. S. ten Brink, P. Buhl, and T. M. Brocher (1985), A multichannel seismic study of lithospheric flexure across the HawaiianEmperor seamount chain, Nature, 315, 105-111.

Wessel, P., and W. H. F. Smith (1991), Free software helps map and display data, Eos Trans. AGU, 72 (41),, 441, 445-446.

White, S. M., J. A. Crisp, and F. J. Spera (2006), Long-term volumetric eruption rates and magma budgets, Geochem. Geophys. Geosys., 7(3), 1-20.

Wohletz, K. H. (1999), MAGMA: Calculates IUGS volcanic rock classification, densities, and viscosities. Los Alamos National Laboratory computer code LA-CC 99-28, Los Alamos New Mexico. 


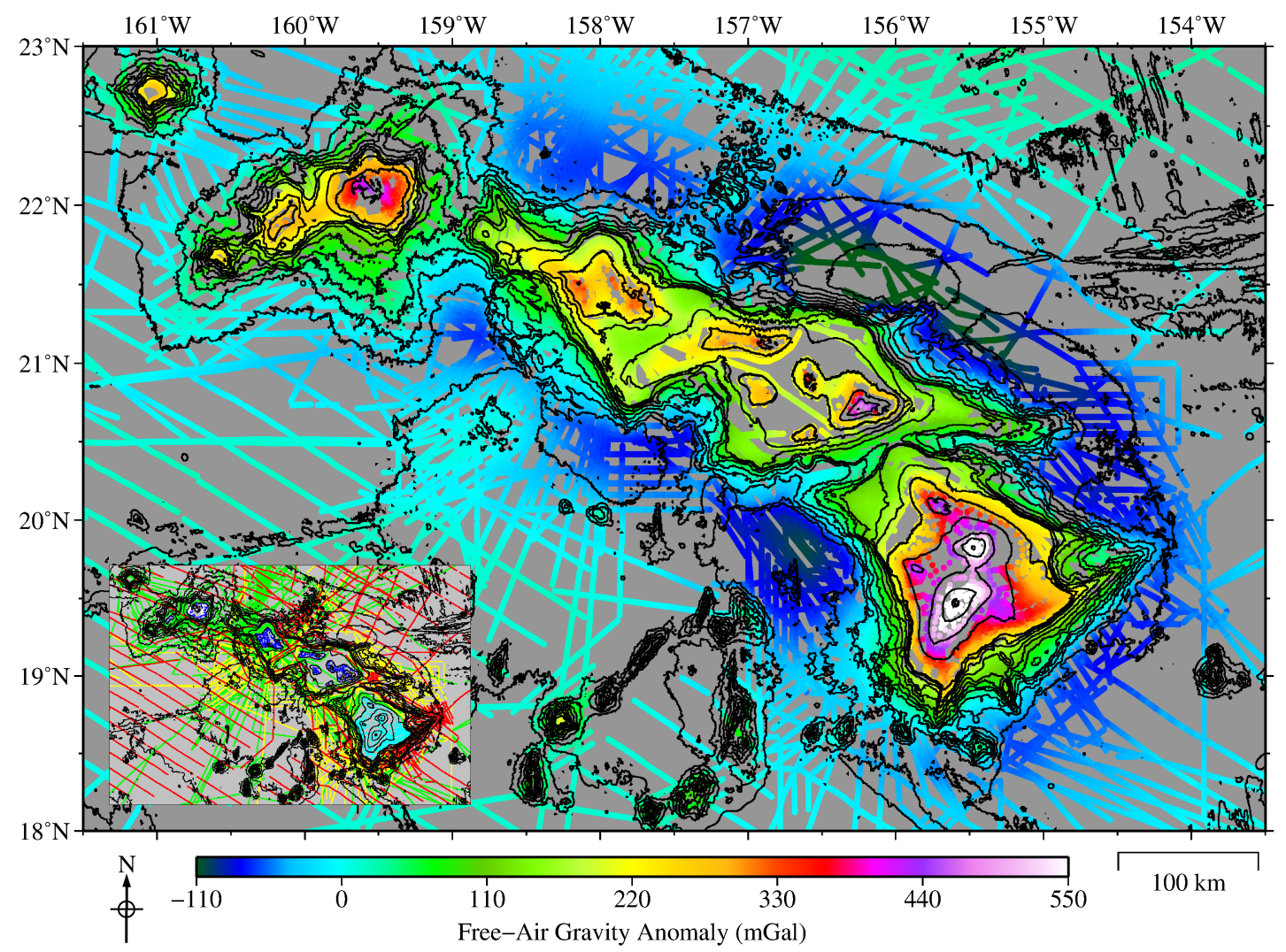

Figure 1.1. Free-air gravity anomalies (FAA) showing high correlation with topography and the long-wavelength swell caused by flexural loading of the oceanic crust. (Inset) Color-coded source data; cyan (Kauahikaua et al., 2000), blue (Strange et al., 1965), white (Flinders et al., 2010), green (R/V Kilo Moana), yellow (JAMSTEC), red $(N G D C)$. 


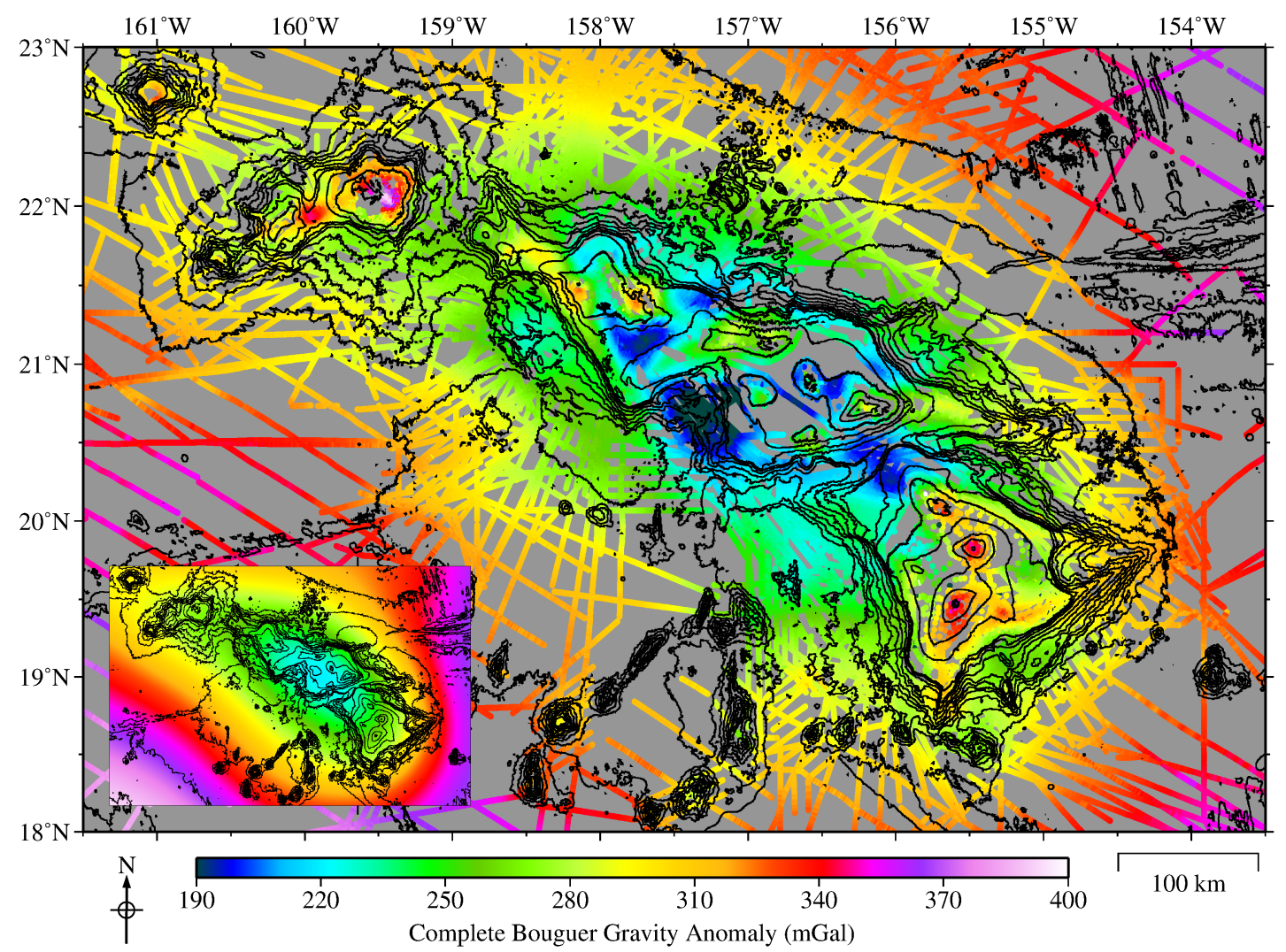

Figure 1.2. Complete Bouguer gravity anomalies calculated using a two-part terrain correction, one for subaerial data one for marine data. (Inset) An estimation of the long-wavelength signal due to flexural deformation of the lithosphere from island loading, using an effective elastic-plate thickness of 30 $\mathrm{km}$, and subsequently removed from the complete Bouguer data to produce the residual gravity data in Figure 1.3. 


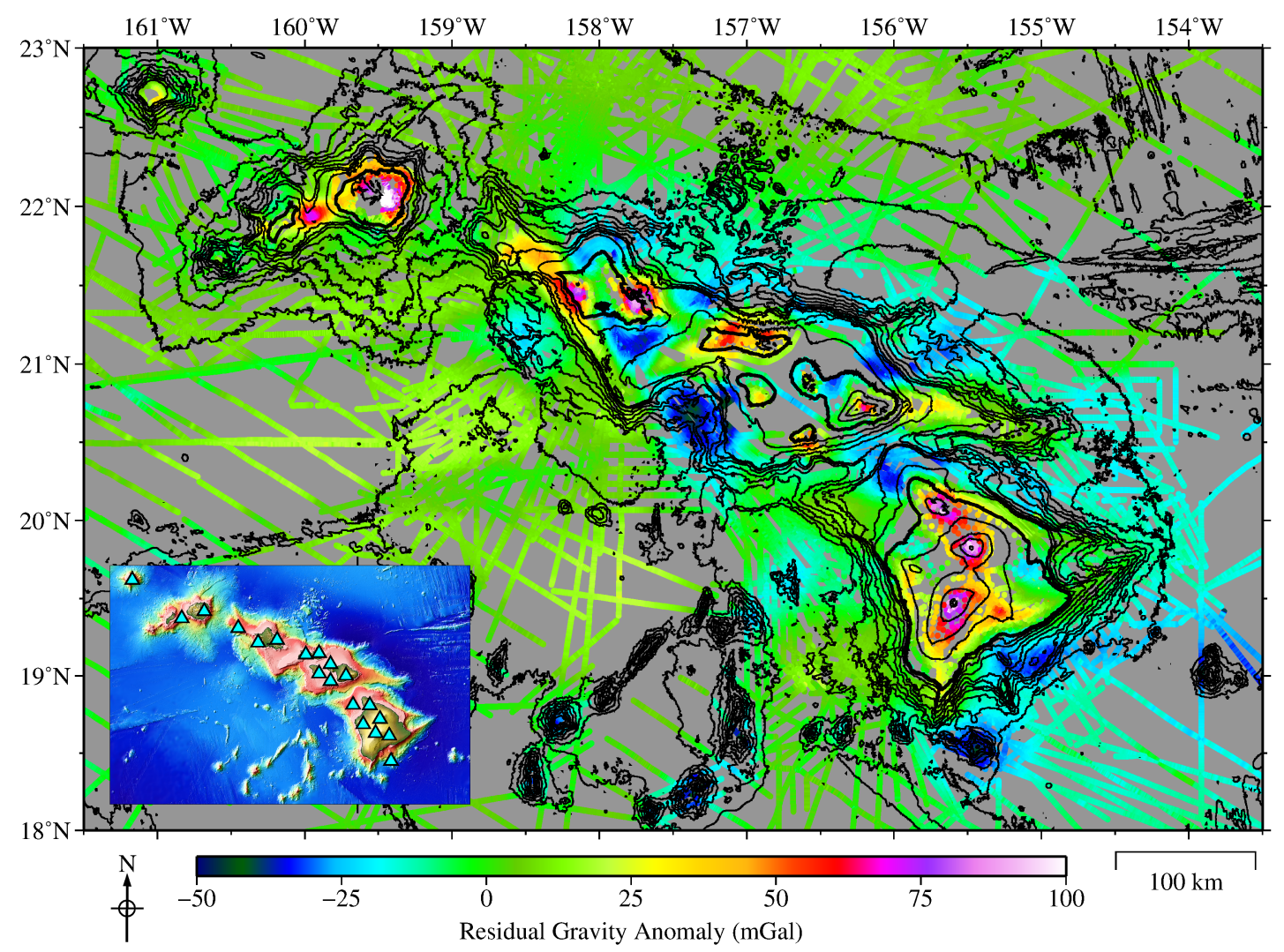

Figure 1.3. Residual gravity anomalies along survey tracks indicate density variations relative to $2.7 \mathrm{~g} / \mathrm{cm}^{3}$. The most positive anomalies are attributed to intrusive-dike complexes and cumulate cores. Residual lows encompass the regions of formerly identified large landslide deposits/slumps, Cretaceous seamounts, and possibly incomplete removal of the long-wavelength flexural signal. Contours show topography/bathymetry at $500 \mathrm{~m}$ intervals. (Inset) Bathymetry of the Hawaiian Island Chain with volcano locations. 


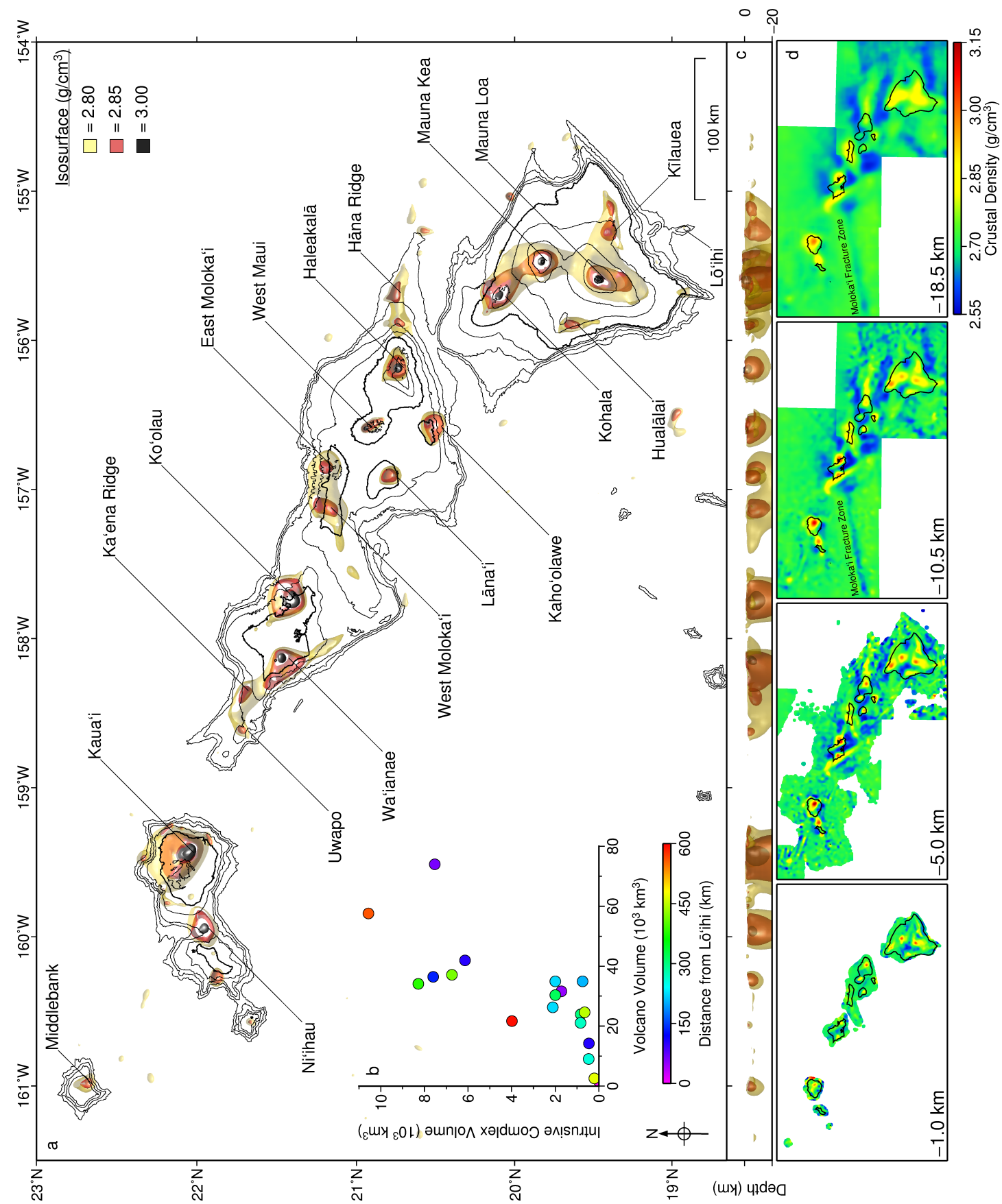

Figure 1.4. (a) Density isosurfaces from the inverted 3D density model. Red surfaces $\left(2.85 \mathrm{~g} / \mathrm{cm}^{3}\right)$ are intrusive complexes, black isosurfaces $\left(3.00 \mathrm{~g} / \mathrm{cm}^{3}\right)$, cumulate cores. Elevation contours at 500/1000 m steps. (b) Island volume/intrusive complex volume. (c) Isosurface view in cross-section along the length of the chain, viewed from the south. (d) Density model at four depths. 


\begin{tabular}{|c|c|c|c|c|c|c|}
\hline & Volume & Isosurface & Avg. p & I.C. ${ }^{\mathrm{a}}$ Vol. & [Olivine] & I.C.Vol. \\
\hline Volcano/Rift & $\left(\mathrm{km}^{3}\right)$ & $\left(\mathrm{g} / \mathrm{cm}^{3}\right)$ & $\left(\mathrm{g} / \mathrm{cm}^{3}\right)$ & $\left(\mathrm{km}^{3}\right)^{\mathrm{b}}$ & $(\%)$ & (\% of Volcano $)^{\mathrm{c}}$ \\
\hline Hualālai & 14,200 & 2.85 & 2.87 & 450 & $6-7$ & 3 \\
\hline Mahukona & 13,500 & $\mathrm{~N} / \mathrm{A}$ & $\mathrm{N} / \mathrm{A}$ & $\mathrm{N} / \mathrm{A}$ & $\mathrm{N} / \mathrm{A}$ & $\mathrm{N} / \mathrm{A}$ \\
\hline \multirow[t]{2}{*}{ Kaho'olawe } & 26,300 & 2.85 & 2.90 & 2,100 & $12-16$ & 8 \\
\hline & & 3.00 & 3.02 & 50 & $37-47$ & $<1$ \\
\hline \multirow[t]{2}{*}{ Läna'i } & 21,100 & 2.85 & 2.90 & 850 & $11-14$ & 4 \\
\hline & & 3.00 & 3.02 & 30 & $37-48$ & $<1$ \\
\hline W Moloka'i & 30,300 & 2.85 & 2.87 & 2,000 & $4-5$ & 7 \\
\hline \multirow[t]{2}{*}{ Wai'anae } & 37,100 & 2.85 & 2.90 & 6,750 & $11-14$ & 18 \\
\hline & & 3.00 & 3.03 & 270 & $41-52$ & $<1$ \\
\hline Uwapo & 2,525 & 2.85 & 2.88 & 200 & $6-8$ & 8 \\
\hline \multirow[t]{2}{*}{ Ni'ihau } & 21,700 & 2.85 & 2.91 & 4,000 & $14-17$ & 18 \\
\hline & & 3.00 & 3.02 & 300 & $38-49$ & 1 \\
\hline Middlebank & $\mathrm{N} / \mathrm{A}$ & 0.15 & 2.87 & 350 & $5-6$ & $\mathrm{~N} / \mathrm{A}$ \\
\hline \multirow[t]{2}{*}{ Kilauea } & 31,600 & 2.85 & 2.88 & 1,700 & $6-7$ & 5 \\
\hline & & 3.00 & 3.03 & $<10$ & $40-51$ & $<1$ \\
\hline \multirow[t]{2}{*}{ Pu'u 'óóó } & & 2.85 & 2.87 & 460 & $5-7$ & $<1$ \\
\hline & & 3.00 & 3.01 & $<10$ & $37-47$ & $<1$ \\
\hline \multirow[t]{2}{*}{ Mauna Kea } & 41,900 & 2.85 & 2.90 & 6,150 & $10-13$ & 15 \\
\hline & & 3.00 & 3.03 & 230 & $39-51$ & 1 \\
\hline \multirow[t]{2}{*}{ Kohala } & 36,400 & 2.85 & 2.90 & 7,600 & $11-14$ & 21 \\
\hline & & 3.00 & 3.02 & 240 & $37-48$ & $<1$ \\
\hline \multirow[t]{2}{*}{ Haleakalā } & 34,900 & 2.85 & 2.92 & 2,000 & $15-19$ & 6 \\
\hline & & 3.00 & 3.05 & 230 & $45-58$ & 1 \\
\hline Hāna Ridge & 34,900 & 2.85 & 2.88 & 750 & $6-7$ & 2 \\
\hline \multirow[t]{2}{*}{ West Maui } & 9,000 & 2.85 & 2.94 & 450 & $19-25$ & 5 \\
\hline & & 3.00 & 3.12 & 70 & $59-76$ & 1 \\
\hline E Moloka'i & 23,900 & 2.85 & 2.87 & 850 & $4-5$ & 3 \\
\hline \multirow[t]{2}{*}{ Ko'olau } & 34,100 & 2.85 & 2.93 & 8,300 & $18-23$ & 24 \\
\hline & & 3.00 & 3.04 & 1,160 & $42-54$ & 3 \\
\hline Ka'ena & 24,575 & 2.85 & 2.86 & 650 & $2-3$ & 3 \\
\hline \multirow[t]{2}{*}{ Kaua'i } & 57,600 & 2.85 & 2.94 & 10,550 & $19-25$ & 19 \\
\hline & & 3.00 & 3.07 & 1,870 & $49-63$ & 3 \\
\hline \multicolumn{7}{|c|}{ 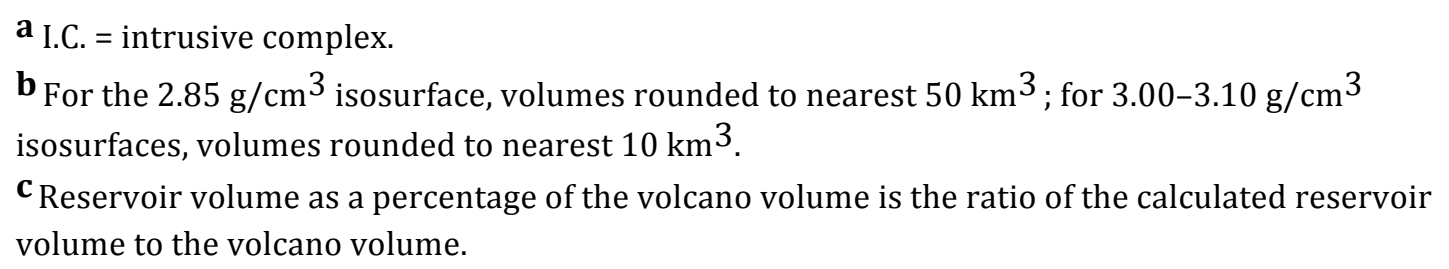 } \\
\hline
\end{tabular}




\title{
MANUSCRIPT 2
}

Seismic evidence for multi-level magmatic plumbing systems in the crust beneath southwest Washington

by

\author{
Ashton F. Flinders ${ }^{1}$, Yang Shen ${ }^{1}$
}

In Preparation Nature, May 2016

${ }^{1}$ Graduate School of Oceanography, University of Rhode Island, Narragansett, RI 02882 


\section{Abstract}

The crustal pathways connecting deep sources of melt generation and the active volcanoes they supply are often poorly understood. At Mount Rainier, an andesitic-forearc stratovolcano in the Cascade Range (Washington state, USA), the effect these pathways have on the volcano's crustal magma reservoirs remains unclear. Previous studies show that subduction-induced ascending melts/fluids, generated by partial melting in the mantle wedge, are offset $\sim 20$ $\mathrm{km}$ west of volcano ${ }^{1,2}$. To the south, the volcano lies on the margins of a proposed extensive zone of mid-crustal partial melt ${ }^{3}$. Here we present a new 3D shear-wave velocity model revealing in great detail the relations of these regions to Mount Rainier's magmatic system. We image two zones of reduced velocity correlating with these regions. We interpret the southern zone, as a proposed but till now never imaged "hot-zone", indicative of large-scale basaltic sill emplacement and silicic differentiation 4 . While this "hot-zone" likely supplies evolved basaltic, andesitic and dacitic magmas to the surrounding volcanoes and vents, including Mount St. Helens and Adams, its contribution to Mount Rainier is minimal. Instead, ascending basaltic-melts/fluids focus as an extended-NS shallow reservoir $20 \mathrm{~km}$ west of Mount Rainier. This reservoir connects to another low-velocity body directly beneath the volcano, interpreted as its central magma reservoir. There is no deep-seated source beneath the central reservoir and we argue that the two laterally connected reservoirs form a multireservoir system as suggested by petrogenic models 5 . 
While arc volcanism originates with the subduction-induced partial melting of the upper mantle, melt pathways can be influenced by buoyancy forces, corner flow, and preexisting lithologies. These effects exert control on the location of intracrustal volcanic reservoirs, seen for example at Mount Merapi (Central Java) and Klyuchevskoy (Kamchatka), where melt travels through several off-axis reservoirs before erupting at the surface ${ }^{6,7}$. Similarly, at Mount Rainier, petrogenetic models suggest crystallization and differentiation in multilevel reservoirs ${ }^{5,8}$, where small batches of magma stall as mid-crustal intrusions, often crystallizing to completion, and assimilate evolved continental sediments 5 . Subsequent injections of new magma mix with these residual silicic melts as they ascend to a shallow central reservoir ${ }^{5,8}$.

Although previous tomographic studies were limited ${ }^{9,10}$, the central reservoir of Mount Rainier has been coarsely imaged as an $\sim 10 \mathrm{~km}$-wide by 14 km deep slow P-wave velocity $\left(\mathrm{V}_{\mathrm{p}}\right)$ zone ${ }^{9}$. A second, NS trending slow $\mathrm{V}_{\mathrm{p}}$ zone, 20 $\mathrm{km}$ to the west ${ }^{8}$, overlaps with a linear aeromagnetic low ${ }^{11}$, a region of increased shallow seismicity (Western Rainier Seismic Zone, WRSZ; Fig. 2.2) ${ }^{9}$, and a large regional anticline (Carbon River; CR) containing exposed Eocene sandstones and shales ${ }^{11}$ (Fig. 2.2a, brown dashed line). These anomalies are assumed unrelated to the volcano's magmatic system, instead attributed to a proposed sedimentary basement underlying the anticline ${ }^{9,11}$. At the northern end of this zone, an EW magnetotelluric (MT) profile imaged ascending fluid/melt from the top of the subducting slab to a $10 \mathrm{~km}$ deep, high-conductivity reservoir, $\sim 28 \mathrm{~km} \mathrm{NW}$ of the volcano $^{1,2}$ (Fig. 2.1/2.2a, purple star). While this reservoir may provide melt to 
central reservoir beneath the volcano, it is unclear that the MT-derived interpretations can be extended the necessary $20 \mathrm{~km}$ southward, particularly given they show a resistive body at the projected location of the actual volcano. So the magma pathways between this deep source and the central reservoir remain elusive.

South of the volcano, widely spaced MT profiles broadly outline a highconductivity zone, the Southern Washington Cascades Conductor (SWCC) ${ }^{11}$, between Mounts St. Helens, Adams and Rainier (Fig. 2.1). A high-resolution MT profile between Mounts St Helens and Adams, verified the southern extent of this zone, imaging a $10 \mathrm{~km}$ thick tabular mid-crustal anomaly extending upwards to shallow reservoirs beneath both volcanoes ${ }^{3}$. While the SWCC was originally interpreted as a large swath of sedimentary basement ${ }^{11}$, it is likely a region of partial evolved melt supplying andesitic-dacitic magmas to these volcanoes ${ }^{3}$. A single MT measurement south of Mount Rainier ${ }^{11}$, along with high heat-flow values in the surrounding area ${ }^{17}$, suggest the SWCC could extend as far north as Mount Rainier and be related to its magmatic system (Fig. 2.1).

Uncertainties in the crustal pathway of the ascending melt and its relationship to Mount Rainier's magmatic reservoir system remain. Does the volcano's central reservoir tap the northwestern high-conductivity reservoir, a deeper crustal reservoir directly beneath the volcano, or the SWCC, as Mounts St. Helens and Adams do? Is there a relationship between the melt pathways and the magma compositions at these three volcanoes? To address these questions, we solved for the crustal shear-wave velocity $\left(V_{s}\right)$ structure of the Mount Rainier 
area using a novel 3D full-waveform tomographic method ${ }^{17,19}$ and all available ambient noise data for the region (see supplementary). We account for phenomena rarely considered but increasingly important at this scale, including; the complex 3D spatial sensitivity of wave propagation, scattering of shortperiod waves by topography, and $\mathrm{P} / \mathrm{S}$ wave-velocity cross-dependence $18,19,20$. Despite the geologic complexity of the region, detailed correlations are seen between the velocity structure and previously mapped lithologies (Fig. 2.2a).

Beneath Mount Rainier we observe a 7 by $11 \mathrm{~km}$ slow $\mathrm{V}_{\mathrm{S}}$ zone $(<85 \%$ $\mathrm{V}_{\mathrm{S}_{-} \text {Exp. }}$ of $3.64 \pm .02 \mathrm{kms}^{-1}$, for diorite at $5 \mathrm{~km}$ and $\left.\sim 175^{\circ} \mathrm{C}\right)^{21}$ oriented NW/SE, displaced slightly east of the summit (Fig. 2.2a, $\Delta$ MR). The zone extends from 1 to $8 \mathrm{~km}$ depth, with an average $\mathrm{V}_{\mathrm{s}}$ of $3.0 \mathrm{kms}^{-1}$, is aseismic, and coincides with the previously observed slow $V_{\mathrm{P}}$ central reservoir8. These depths agree with the $>7$ km magma source depth, derived from melt inclusion volatile concentrations, in andesites from the 2.2 Ka eruption ${ }^{6}$. No second, mid-crustal, reservoir was found beneath the volcano, and although traces of marginally reduced velocity extend to $16 \mathrm{~km}$, they quickly trend back to the regional basement velocity.

A much larger, NS trending, slow $V_{S}$ zone is located $\sim 15 \mathrm{~km}$ west of Mount Rainier, coinciding with the WRSZ (Fig. 2.2a). While the contiguous portion terminates $\sim 7 \mathrm{~km}$ north of the volcano, isolated pockets extend to the shallow reservoir imaged by $\mathrm{MT}^{1,2}$. Unlike beneath Mount Rainier, the slow $\mathrm{V}_{S}$ zone can be seen well past $16 \mathrm{~km}$ depth, forming a gradual extension of a larger mid crustal zone associated with the SWCC (Fig. 2.3). Additionally, an eastward prolongation of the zone connects to the volcano's central reservoir (Fig. 2.2b). 
We propose that melt ascends from the deeper crust to within the WRSZ, undergoes crystallization and mixing, before moving laterally eastward into the central reservoir. The slow seismic velocities, aeromagnetic low, and increased seismicity are caused by both the ascending melt, and the large Eocene sediment layer into which it intrudes.

Lateral migration of magma from this off axis-western reservoir to the central reservoir is supported by the geochemical (major and trace elements) and isotopic ( $\mathrm{Sr}, \mathrm{Nd}, \mathrm{Pb}, \mathrm{O})$ compositions of the volcano's products which are consistent with modest assimilation (typically $\leq 20 \mathrm{wt} \%$ ) of evolved sediment ${ }^{5}$. While it's been proposed that this assimilation occurs in a deep mid-crustal central reservoir ${ }^{5}$, we find no evidence for a sediment sequence beneath the volcano.

We image the SWCC as a large slow $V_{S}$ zone between Mounts St. Helens, Adams and Rainier, with a broad base extending to at least $25 \mathrm{~km}$ depth (Fig. 2.3). The lateral boundaries are visible upwards to $\sim 12 \mathrm{~km}$ depth before becoming lost in the complex upper crust. Although on the margin of our resolution, we observe the same general upward extension of the SWCC to reservoirs beneath Mount Adams and St. Helens, as seen in conductivity studies ${ }^{3}$. While the northern extent of the SWCC terminates $20 \mathrm{~km}$ south of Mount Rainier, an extension of the northwestern corner underlies the WRSZ. These observations agree with the interpretation of the SWCC as a mid-crustal zone of partial melt ${ }^{3}$, which may also extend under the WRSZ. 
Numerical modeling supports the conclusion that at subduction zones, the ascending hydrous-basaltic melt phase is emplaced as a succession of sills into the lower crust ${ }^{4}$. These sills generate "hot-zones", where the mantle-derived basalt undergoes various degrees of crystallization to produce residual intermediate-to-silicic $\mathrm{H}_{2} \mathrm{O}$-rich melts, as well as cause partial melting of preexisting crustal rocks ${ }^{4}$. As these "hot-zones" evolve, gradients develop in the zone's temperature, pressure, $\mathrm{H}_{2} \mathrm{O}$ content, and melt fraction, producing the wide range of geochemical variation seen in $\operatorname{arc}$ magmas $^{4}$. Further inhomogeneity could also be driven by the varying depth to the subducting slab beneath the "hot-zone" (Fig. 2.1), and relative contributions of intraplate versus slab-derived components. This process provides a plausible mechanism to explain the SWCC. The predominant andesitic-dacitic magmas erupted from Mount St. Helens and Adams likely originate from this geochemical varied zone. In agreement with this successive sill model, more primitive basalts, such as those erupted from minor peripheral vents around Mounts Rainier and Adams, are thought to originate from independent conduits to deeper crustal or mantle reservoirs ${ }^{5,22}$. While it is clear the northwestern extension of the SWCC goes under the WRSZ, to what extent of the magma under the WRSZ comes directly from the mantle wedge below or from the "hot-zone" is unclear. Nevertheless the spatial extent of SWCC slow $V_{S}$ suggests it is likely one of the primary loci of ascending melt in the region, inline with the Mount Hood-to-Adams segment of main arc stratovolcanoes. 
The proximal relationship between Mount Rainier's western reservoir and the large mid-crustal zone of partial-melt tapped by Mount St. Helens provides a possible explanation for geochemical similarities/differences between their products. Andesites and dacites from Mount St. Helens have distinctly lower $\mathrm{K}_{2} \mathrm{O}$ concentrations and ${ }^{206} \mathrm{~Pb} /{ }^{204} \mathrm{~Pb}$ ratios than those from Mount Rainier and Adams5 ${ }^{5}$ However, small amounts of Mount St. Helens-like magmas contribute to the Mount Rainier magmatic system7. Mount Rainier samples selected for lower-than typical $\mathrm{K}_{2} \mathrm{O}$ concentrations also display low ${ }^{206} \mathrm{~Pb} /{ }^{204} \mathrm{~Pb}$, and approach Mount St. Helens $\mathrm{Nd}-\mathrm{Sr}-\mathrm{Pb}$ isotope values ${ }^{5}$. This could result from the imaged western margin of the SWCC incorporating portions of the eastern edge of the Siletzia terrane ${ }^{5}$ (Fig. 2.1/2.3), modified by incorporation of sediment with lower ${ }^{143} \mathrm{Nd} /{ }^{144} \mathrm{Nd}$ and higher ${ }^{87} \mathrm{Sr} /{ }^{86} \mathrm{Sr},{ }^{207} \mathrm{~Pb} /{ }^{204} \mathrm{~Pb}^{7}$. Mount St Helens and the southwestern extent of the SWCC, are separated from the Siletzia basement by only a narrow band of early Cascadia-arc rocks, consistent with a stronger assimilation of Siletzia-influenced partial melt. However, Mount Rainier further east of the Siletzia boundary and further north of the SWCC, exhibits a relatively minor but still detectable contribution. Mount Adams, being far from the Siletzia boundary, shows no ${ }^{206} \mathrm{~Pb} /{ }^{204} \mathrm{~Pb}$ evidence for its incorporation ${ }^{5}$. Similarly, there is no $\mathrm{Nd}-\mathrm{Sr}-\mathrm{Pb}$ isotope evidence for crustal sediment assimilation in Mount Adam's magmas ${ }^{5}$, which would be expected if the SWCC was predominantly sedimentary as proposed in the past.

The slow $V_{p}$ of the central reservoir beneath Mount Rainier was loosely constrained to the combined effects of heated rock and a small melt fraction'. 
With our new model, we can provide more constraints on individual contributions. Oxide geothermometry has shown a pre-eruptive temperature of $980^{\circ} \mathrm{C}$ for central-reservoir andesites ${ }^{8}$, supported by the aseismicity of the slow $\mathrm{V}_{\mathrm{S}}$ zone suggesting temperatures above the brittle-ductile transition (600$\left.900^{\circ} \mathrm{C}\right)^{23}$. Although no experimentally derived $V_{s}$ temperature derivative for diorite was available, we can use the range given by granite $\left(-.21 \times 10^{-3} \mathrm{kms}^{-1} \mathrm{C}^{-1}\right)$ and perdotite $\left(-.39 \times 10^{-3} \mathrm{kms}^{-1} \mathrm{C}^{-1}\right)$ end-members as a proxy ${ }^{24}$. The $980^{\circ} \mathrm{C}$ elevated reservoir temperature, above the $35^{\circ} \mathrm{C} \mathrm{km}^{-1}$ geothermal gradient ${ }^{17}$, accounts for $\sim 38 \%$ of our observed slow $V_{S}$. We attribute the remaining to fractional interstitial melt. Shear-wave velocity versus crystal-fraction experiments for a synthetic crystal-liquid suspension with $\sim 5$ wt $\% \mathrm{H}_{2} \mathrm{O}^{25}$, extrapolated to the $980^{\circ} \mathrm{C}$ reservoir temperature ${ }^{8}$, estimates that each percent of interstitial melt leads to a decrease in $\mathrm{V}_{\mathrm{S}}$ of $\sim 2.0 \%$, with the residual slow $\mathrm{V}_{\mathrm{S}}$ accounted for with $\sim 5 \%$ melt.

While estimates of the reservoir volume will vary widely with smallchanges in the velocity threshold, our melt fraction is robust. For comparison, we calculate the melt fraction for the Mount St Helens central magma reservoir (Fig 2.2a, $\triangle \mathrm{MSH}$; $\mathrm{T}_{\text {res. }}=850^{\circ} \mathrm{C}, \mathrm{V}_{\mathrm{S}_{-} \text {exp. }}=3.61 \mathrm{kms}^{-1}, \mathrm{~V}_{\mathrm{S}} / \mathrm{T}=-.21 \times 10^{-3} \mathrm{kms}^{-1} \mathrm{C}^{-1}$ ), for two thresholds. The first $\left(<85 \% \mathrm{~V}_{\mathrm{S}_{-} \exp }\right)$ results in a melt fraction of $8.9 \%$, and a reservoir volume of $375 \mathrm{~km}^{3}$. As tomography provides average $\mathrm{V}_{\mathrm{s}}$ solutions over spatial scales larger than individual melt-filled dikes, sills, and fissures, it will generally overestimate volumes and underestimate melt-fractions. To account for this, we adjust the threshold until the reservoir volume is equal to 
the volume found through geodetic modeling of the 2004-2006 eruptive period $\left(17 \mathrm{~km}^{3}\right)^{26}$, providing a comparable melt fraction of $8.5 \%$. Melt fractions for both Mount Rainier and St. Helens are within the ranges found for other reservoirs using seismic tomography; < 4\% melt Taupu Volcano ${ }^{27}, 10 \%$ melt Kilauea's East Rift Zone ${ }^{28}$, and 3-10\% melt Soufrière Hills ${ }^{29}$.

We can also estimate the melt-fraction of the SWCC by assuming its velocity is a deviation from the eastern regional mid/deep-crustal bedrock. Confining the SWCC to a contiguous body, separate from Mount Rainier's western sediment/melt reservoir, yields an estimated volume of $>28,300 \mathrm{~km}^{3}$, with an average reduced $V_{S}$ of $8.4 \%$ (Fig. 2.3). Each percent of interstitial melt leads to a decrease in $\mathrm{V}_{S}$ of $\sim 1.5-2 \%{ }^{25}$, leading to an average melt-fraction of 5.1 $\pm 1.3 \%$. At this melt fraction, theoretical temperature estimates ${ }^{4}$ are only 50 $75^{\circ} \mathrm{C}$ above the assumed geothermal gradient ${ }^{17}$, implying a minimal thermal contribution of $<0.5 \%$ to the reduced velocity. This volume of melt is more than twice the total eruptive volume of the six main Quaternary eruptive centers from Mounts Hood to Rainier, combined 22.

We propose that the partial-melt SWCC province is the primary reservoir of of the region's Quaternary arc magmatism in the deep crust, and the crustal expression of subduction-driven mantle melange diapirs ${ }^{30}$. Compositional variations in the volcanoes are, in part, controlled by their location relative to the SWCC, and the subsurface pathways of the ascending hydrous-basaltic melt phase. Mount Rainier stands on the SWCC's diminishing northern margin, which coincides with an abrupt ending of the nearly continuous Mount Hood to Rainier 
segment of the arc. The next Quaternary cluster to the north (south of Glacier Peak) is separated by a $120 \mathrm{~km}$-long-gap (Fig. 2.1). We hypothesize that the volcanic segments and gaps may be controlled by SWCC-like crustal "hot-zones" throughout the entire $1100 \mathrm{~km}$-long Cascades arc. Differences in volcanism between the Mount Hood to Rainier segment and the neighboring Garibaldi Volcanic belt to the north and the Oregon Cascades Segment to the south could be partially attributed to the size and emplacement of these crustal "hot zones". Further imaging of the middle to deep crust across the length of the arc is needed to confirm these crustal provinces. Correlating their locations/extents to Quaternary volcanic centers/intrusions will provide valuable insight on the timescales involved for active volcanism and material cycling in subduction zones.

\section{Methods}

Source data is derived from the cross-correlation of ambient noise waveforms, a well proven technique to reconstruct Empirical Green's Function between two seismic-station pairs, i.e. one stations far-field response to an impulsive source at the paired station. While application of ambient noise records to volcanic seismic tomography has become more popular, wave modeling in general has been limited to classical approaches (non-3D/ray-based methods). Ray-based methods assume that the propagation time of a simulated wave from source-to-receiver is only sensitive to velocity perturbations along a line-path connecting the two locations. This assumption does not account for the 
3D spatial sensitivity of wave propagation, which is necessary to accurately invert for a complex 3D velocity model. Despite being relatively novel, 3D fullwaveform methods have been shown to yield improved data fits over classical non-3D/ray-based approaches ${ }^{31,32}$.

Our full-wave tomographic method accounts for complex wave propagation using an iterative approach. Each iteration is comprised of (1) finite-difference wave propagation simulations, (2) measurement of phase delays between observed (EGFs) and synthetic waveforms, (3) calculation of 3D P/S-wave sensitivity kernels using the strain Green tensor scattering-integral approach $^{12}$, (4) inversion for velocity perturbations and (5) updating the velocity model. We include a brief discussion on preparation of the EGFs and simulation/inversion parameters, and full details of the method can be found in Gao and Shen (2014).

\section{Empirical Green's Functions}

Empirical Green's functions (EGFs) were extracted from short-period (EHZ) and broadband (BHZ) high-gain vertical-component seismic stations within $110 \mathrm{~km}$ of Mt. Rainier (Fig. S2.1; 99 stations total). Data requests were made through the Incorporated Research Institution for Seismology (IRIS) Data Management Center, and limited to the years 2000-2014. Processing included removing the seismometer instrument response, cutting the records into daily segments, and normalizing their spectra. Normalization was performed via the frequency-time normalization method ${ }^{33}$ using $4 \mathrm{~Hz}$ wide frequency bands. 
Portions of seismic records overlapping with large earthquakes $(M>5.0)$ were nulled and tapered. Daily records for unique station-station pair combinations were cross-correlated and stacked by month, and EGFs calculated as their time derivative. EGF's for months with a signal-to-noise ratios $<5$ were removed from the database. This discrimination removed months where instruments were behaving erratically or when there was localized coherent noise. All daily crosscorrelations for remaining months were then stacked into a total crosscorrelation record, and subsequent EGFs calculated (Fig. S2.1/S2.2; 2607 EGFs).

\section{Full-Waveform 3D Simulation and Inversion}

Empirical Green's functions were modeled synthetically by simulating the propagation of a Rayleigh surface wave between two station-station pairs using a cartesian version of the 3D nonstaggered-grid finite-difference method of Zhang et al. (2012). A vertical surface perturbation, with a Gaussian source-time function and a half width of $1 \mathrm{~s}$, was forced at a station location and the resultant surface velocity was used to calculate the synthetic Green's functions (SGFs) for all stations paired with the source station (Fig. S2.4). Full 3D tensor volumes were saved for each simulation and later used to calculate 3D P/S-wave sensitivity kernels (Fig. S2.6). Delay times between SGFs and EGFs were then calculated for a range of discrete overlapping frequency bands (Fig. S2.5). For computational efficiency and solution stability, the long-wavelength velocity structure of the region was solved for first. Iterations 1 - 8 used a $500 \mathrm{~m}$ xy grid spacing and the frequency bands (4.5 - 9 s, 6.75 - 13.5 s, 10.125 - 20.25 s), while 
iterations 9 - 10 used a $250 \mathrm{~m}$ xy grid spacing and two additional frequency bands (2 - 4 s, 3 - 6 s). Vertical grid spacing was constant through all iterations and graded from $200 \mathrm{~m}$ near the surface to $1 \mathrm{~km}$ at the base of the model. The simulation extended to $90 \mathrm{~km}$ depth, and used a starting model derived from a previous regional shear-wave ambient noise tomography model (Fig. S2.3) ${ }^{32}$.

\section{Acknowledgments.}




\section{References}

1. McGary, R. S., Evans, R. L., Wannamaker, P. E., Elsenbeck, J. \& Rondenay, S. Pathway from subducting slab to surface for melt and fluids beneath Mount Rainier. Nature 511, 338-340 (2014).

2. Wannamaker, P. E. et al. Segmentation of plate coupling, fate of subduction fluids, and modes of arc magmatism in Cascadia, inferred from magnetotelluric resistivity. Geochem. Geophys. Geosyst. 15, 4230$4253(2014)$.

3. Hill, G. J. et al. Distribution of melt beneath Mount St Helens and Mount Adams inferred from magnetotelluric data. Nat. Geosci. 2, 785-789 (2009).

4. Annen, C., Blundy, J. D. \& Sparks, R. S. J. The Genesis of Intermediate and Silicic Magmas in Deep Crustal Hot Zones. J. Petrol. 47, 505-539 (2005).

5. Sisson, T. W., Salters, V. J. M. \& Larson, P. B. Petrogenesis of Mount Rainier andesite: Magma flux and geologic controls on the contrasting differentiation styles at stratovolcanoes of the southern Washington Cascades. Geol. Soc. Am. Bull. 126, 122-144 (2013).

6. Wagner, D. et al. Joint inversion of active and passive seismic data in Central Java. Geophys. J. Int. 170, 923-932 (2007). 
7. Koulakov, I. et al. Feeding volcanoes of the Kluchevskoy group from the results of local earthquake tomography. Geophys. Res. Lett. 38, L09305 (2011).

8. Venezky, D. Y. \& Rutherford, M. J. Preeruption conditions and timing of dacite-andesite magma mixing in the 2.2 ka eruption at Mount Rainier. J. Geophys. Res. 102, 20069-20086 (1997).

9. Moran, S. C., Lees, J. M. \& Malone, S. D. Pwave crustal velocity structure in the greater Mount Rainier area from local earthquake tomography. J. Geophys. Res. 104, 10775-10786 (1999).

10. Obrebski, M., Abers, G. A. \& Foster, A. Magmatic arc structure around Mount Rainier, WA, from the joint inversion of receiver functions and surface wave dispersion. Geochem. Geophys. Geosyst. 16, 178-194 (2015).

11. Stanley, W. D., Finn, C. \& Plesha, J. L. Tectonics and conductivity structures in the Southern Washington Cascades. J. Geophys. Res. 92, 10179 (1987).

12. McCrory, P. A., Blair, J. L., Oppenheimer, D. H. \& Walter, A. S. R. Depth to the Juan de Fuca Slab Beneath the Cascadia Subduction Margin-A 3-D Model for Sorting Earthquakes. USGS Data Series 91, 1-13 (2006).

13. Lees, J. M. \& Crosson, R. S. Tomographic imaging of local earthquake delay times for three-dimensional velocity variation in western Washington. J. Geophys. Res. 95, 4763 (1990).

14. Hammond, P. E. Tertiary Andesitic Lava-flow Complexes (Stratovolcanoes) in the Southern Cascade Range of Washington- 
Observations on Tectonic Processes within the Cascade Arc. Washington Geology 26, 1, 20-30 (1998).

15. Lees, J. M. \& Crosson, R. S. Tomographic inversion for three-dimensional velocity structure at Mount St. Helens using earthquake data. J. Geophys. Res. 94, 5716 (1989).

16. Mattinson, J. M. Emplacement history of the Tatoosh volcanic-plutonic complex, Washington: Ages of zircons. Geol. Soc. Am. Bull. (1977).

17. Blackwell, D. D., Steele, J. L., Kelley, S. \& Korosec, M. A. Heat flow in the state of washington and thermal conditions in the Cascade Range. J. Geophys. Res. 95, 19495 (1990).

18. Zhao, L., Jordan, T. H., Olsen, K. B. \& Chen, P. Frechet Kernels for Imaging Regional Earth Structure Based on Three-Dimensional Reference Models. Seismol. Soc. Am. Bull. 95, 2066-2080 (2005).

19. Zhang, W. \& Shen, Y. Unsplit complex frequency-shifted PML implementation using auxiliary differential equations for seismic wave modeling. Geophysics 75, T141-T154 (2010).

20. Zhang, Z. \& Shen, Y. Cross-dependence of finite-frequency compressional waveforms to shear seismic wave speeds. Geophys. J. Int. 174, 941-948 (2008).

21. Christensen, N. I. Poisson's ratio and crustal seismology. J. Geophys. Res. 101, 3139-3156 (1996).

22. Hildreth, W. Quaternary magmatism in the Cascades-geologic perspectives. U.S. Geol. Surv. Prof. Pap. 1744 (2007). 
23. Tuffen, H., Smith, R. \& Sammonds, P. R. Evidence for seismogenic fracture of silicic magma. Nature 453, 511-514 (2008).

24. Kern, H. \& Richter, A. Temperature derivatives of compressional and shear wave velocities in crustal and mantle rocks at 6 kbar confining pressure. J. Geophys. 49, 47-56 (1981).

25. Caricchi, L., Burlini, L. \& Ulmer, P. Propagation of $\mathrm{P}$ and S-waves in magmas with different crystal contents: Insights into the crystallinity of magmatic reservoirs. J. Volcanol. Geotherm. Res. 178, 740-750 (2008).

26. Mastin, L. G., Lisowski, M., Roeloffs, E. \& Beeler, N. Improved constraints on the estimated size and volatile content of the Mount St. Helens magma system from the 2004-2008 history of dome growth and deformation. Geophys. Res. Lett. 36, L20304 (2009).

27. Heise, W. et al. Melt distribution beneath a young continental rift: The Taupo Volcanic Zone, New Zealand. Geophys. Res. Lett. 34, L14313 (2007). 28. Lin, G., Amelung, F., Lavallee, Y. \& Okubo, P. G. Seismic evidence for a crustal magma reservoir beneath the upper east rift zone of Kilauea volcano, Hawaii. Geology 42, 187-190 (2014).

29. Paulatto, M. et al. Magma chamber properties from integrated seismic tomography and thermal modeling at Montserrat. Geochem. Geophys. Geosyst. 13, 1-18 (2012).

30. Marschall, H. R. \& Schumacher, J. C. Arc magmas sourced from mélange diapirs in subduction zones. Nat. Geosci. 5, 862-867 (2012). 


\section{Methods References}

31. Maceira, M., Larmat, C. \& Porritt, R. W. On the validation of seismic imaging methods: Finite frequency or ray theory? Geophys. Res. Lett. 42, 323-330 (2015).

32. Gao, H. \& Shen, Y. Upper mantle structure of the Cascades from full-wave ambient noise tomography: Evidence for 3D mantle upwelling in the back-arc. Earth Planet. Sci. Lett. 390, 222-233 (2014).

33. Ekström, G., Abers, G. A. \& Webb, S. C. Determination of surface-wave phase velocities across USArray from noise and Aki's spectral formulation. Geophys. Res. Lett. 36, L18301-5 (2009).

34. Zhang, W., Zhang, Z. \& Chen, X. Three-dimensional elastic wave numerical modelling in the presence of surface topography by a collocated-grid finite-difference method on curvilinear grids. Geophys. J. Int. 190, 358378 (2012). 


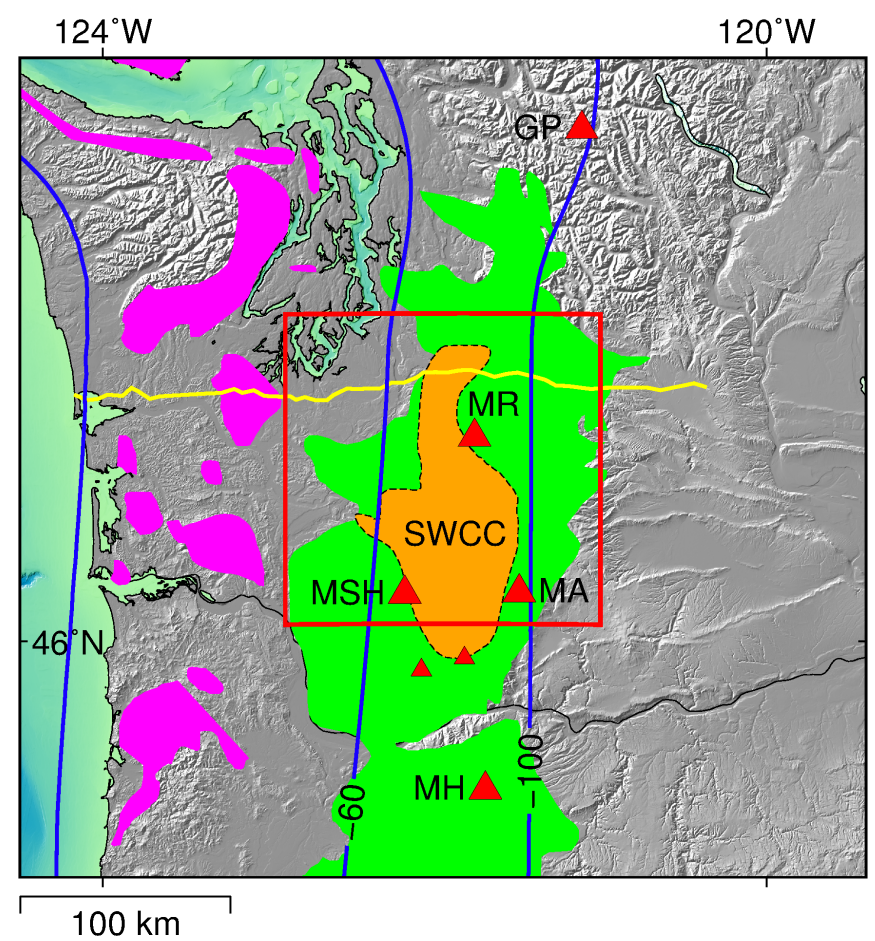

Figure 2.1 | Overview of study area. Study area (red outline), depth to the top of the subducting slab ${ }^{12}$ (blue contours), active Cascade arc volcanos (red triangles), and surface geology5. Geologic units are; Paleocene-middle Eocene submarine basalts of the Siletzia terrain (purple); chiefly Oligocene-Miocene arc igneous rocks (green). Other features; broad conductivity derived SWCC region ${ }^{11}$ (orange); the CAFEs MT line ${ }^{1,2}$ (yellow). Abbreviations given; (GP) Glacier Peak, (MR) Mount Rainier, (MSH) Mount Saint Helens, (MA) Mount Adams, (MH) Mount Hood. 


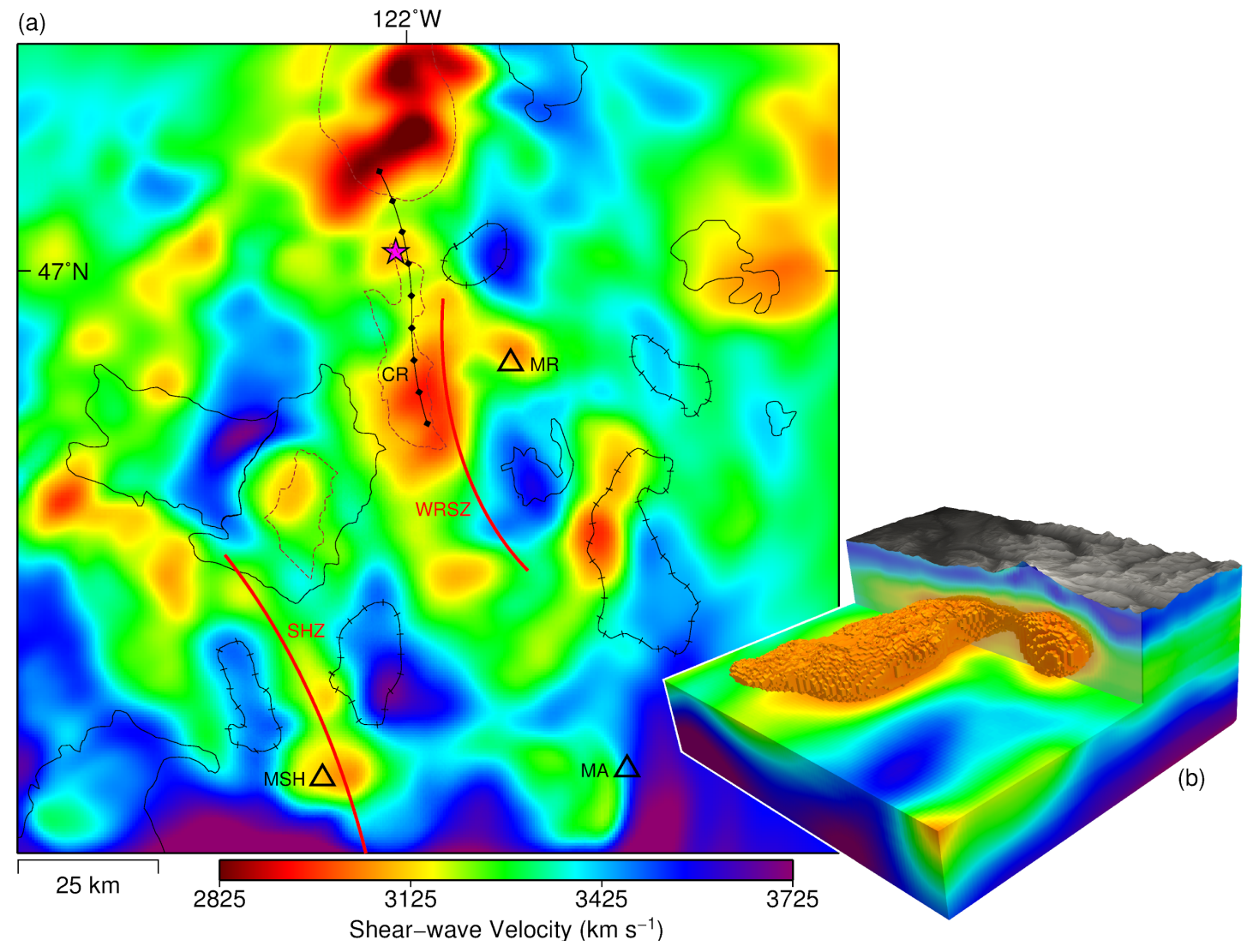

Figure 2.2 | (a) Shear-wave velocity at 8 km depth. Fast/slow $V_{s}$ correlate well with previously mapped lithologies. Sediment deposits ${ }^{13,14}$ (brown-dashed lines) are associated with slow velocities while fast velocities overlap Late Eocene to Early Miocene lava flow complexes ${ }^{14}$ (solid lines) and plutons ${ }^{14,15,16}$ (hachured lines). Central magma reservoirs are observed beneath both Mount Rainier and St. Helen's. Approximate location of the high-conductivity reservoir imaged by McGary et al. (2014) shown as purple star. Abbreviations given; (MR) Mount Rainier, (MSH) Mount Saint Helens, (MA) Mount Adams, (WRSZ) West Rainier Seismic Zone, (SHZ) Saint Helens seismic Zone, (CR) Carbon River Anticline. (b) 3D Perspective of Mount Rainier's magma system. The 
connection between the western sediment/melt body and the central reservoir is seen for the $3.05 \mathrm{~km} \mathrm{~s}^{-1}$ isosurface. 


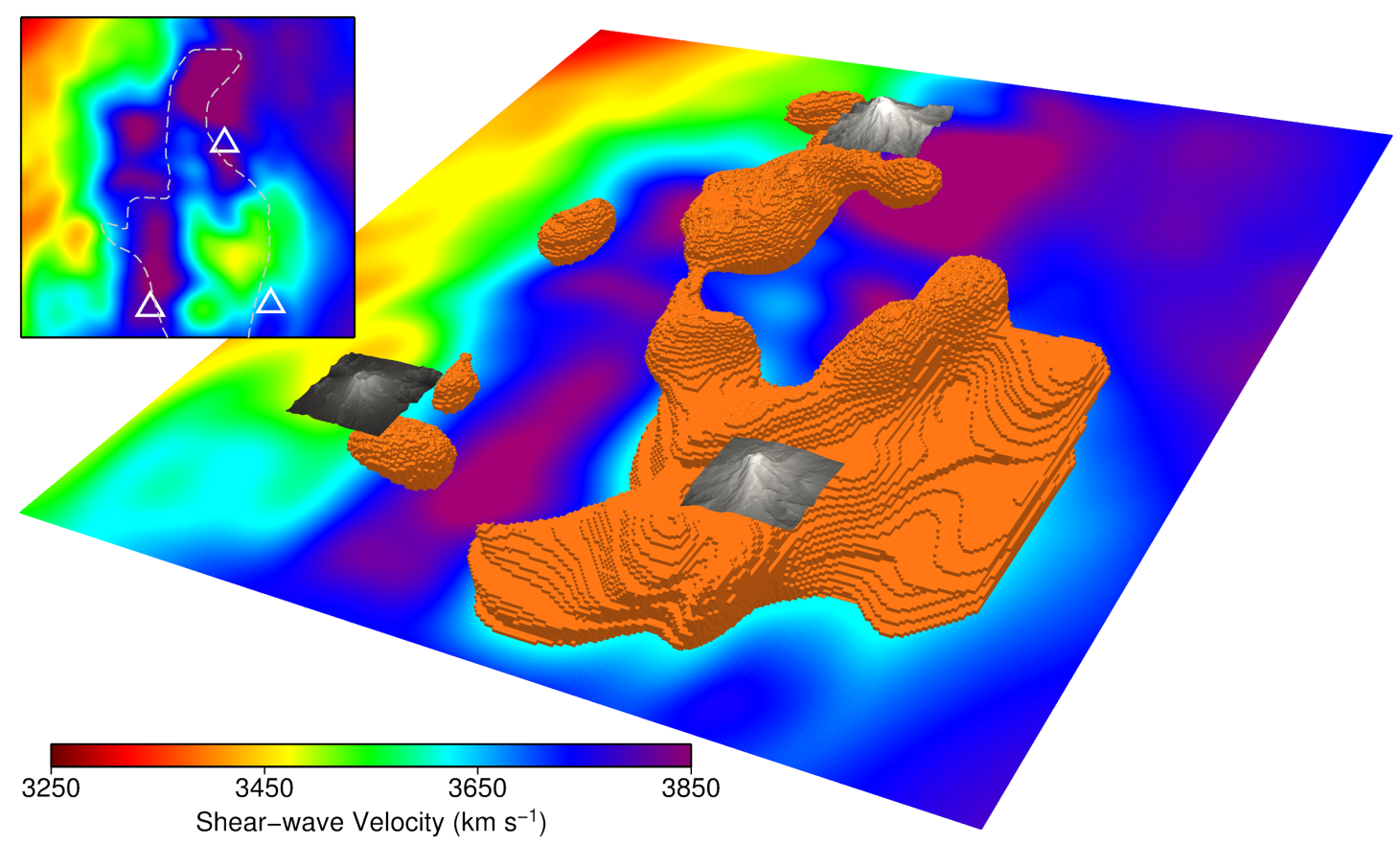

Figure 2.3 | Shear-wave velocity at $22 \mathrm{~km}$ depth and $7 \%$ Slow $\mathrm{V}_{\mathrm{s}}$ Isosurface.

(inset) Showing the boundaries of the broad conductivity derived SWCC ${ }^{11}$ (gray dashed). (main) The SWCC defined by the $>7 \%$ slow $V_{s}$ isosurface (orange body). Additional slow bodies are shown for Mount Rainier's/St. Helen's magmatic system, the SHZ, and the Morton Anticline. 
Table S2.1 | Station Locations and Start/End Times

\begin{tabular}{|c|c|c|c|c|c|c|c|}
\hline \multirow[t]{2}{*}{ Network } & \multirow[t]{2}{*}{ Station } & \multirow[t]{2}{*}{ Latitude } & \multirow[t]{2}{*}{ Longitude } & \multicolumn{2}{|l|}{ Start } & \multicolumn{2}{|l|}{ End } \\
\hline & & & & Year & Day & Year & Day \\
\hline \multirow[t]{12}{*}{ CC } & BLIS & 46.19747 & -122.18657 & 2004 & 293 & 2005 & 30 \\
\hline & JRO & 46.27510 & -122.21780 & 2004 & 366 & 2014 & 312 \\
\hline & MIDE & 46.19775 & -122.18744 & 2005 & 55 & 2005 & 204 \\
\hline & NED & 46.20025 & -122.18549 & 2005 & 55 & 2013 & 118 \\
\hline & OBSR & 46.89972 & -121.81533 & 2013 & 365 & 2014 & 312 \\
\hline & PANH & 46.85900 & -121.64261 & 2013 & 365 & 2014 & 312 \\
\hline & RAFT & 46.19568 & -122.18632 & 2006 & 298 & 2007 & 143 \\
\hline & SPN5 & 46.19470 & -122.18837 & 2007 & 201 & 2007 & 302 \\
\hline & SUG & 46.21555 & -122.17626 & 2009 & 219 & 2009 & 363 \\
\hline & SWF2 & 46.17835 & -122.21677 & 2013 & 365 & 2014 & 313 \\
\hline & SWFL & 46.18867 & -122.20203 & 2007 & 27 & 2012 & 347 \\
\hline & VALT & 46.21422 & -122.18925 & 2013 & 365 & 2014 & 312 \\
\hline \multirow[t]{5}{*}{ PB } & B201 & 46.30330 & -122.26480 & 2007 & 261 & 2014 & 313 \\
\hline & B202 & 46.24470 & -122.13670 & 2007 & 212 & 2014 & 313 \\
\hline & B203 & 46.16900 & -122.33367 & 2007 & 200 & 2014 & 313 \\
\hline & B204 & 46.13600 & -122.16900 & 2007 & 215 & 2014 & 313 \\
\hline & B941 & 46.98680 & -122.21900 & 2008 & 85 & 2014 & 313 \\
\hline \multirow[t]{7}{*}{ TA } & D04A & 47.11090 & -122.80350 & 2007 & 365 & 2008 & 87 \\
\hline & D04D & 47.17860 & -122.77230 & 2010 & 230 & 2012 & 276 \\
\hline & D04E & 47.17860 & -122.77150 & 2013 & 365 & 2014 & 313 \\
\hline & D05A & 47.18810 & -121.98880 & 2006 & 365 & 2008 & 336 \\
\hline & E04A & 46.59340 & -122.72040 & 2005 & 299 & 2008 & 41 \\
\hline & E04D & 46.55660 & -122.56730 & 2010 & 237 & 2014 & 313 \\
\hline & E05A & 46.56050 & -121.76080 & 2005 & 301 & 2008 & 31 \\
\hline \multirow[t]{12}{*}{ UW } & ASR & 46.15259 & -121.60164 & 2000 & 1 & 2014 & 313 \\
\hline & CDF & 46.11689 & -122.04623 & 2000 & 1 & 2014 & 314 \\
\hline & EDM & 46.19717 & -122.15121 & 2000 & 1 & 2014 & 313 \\
\hline & ELK & 46.30539 & -122.34205 & 2000 & 1 & 2013 & 363 \\
\hline & FMW & 46.94139 & -121.67101 & 2000 & 1 & 2014 & 313 \\
\hline & GHW & 47.04149 & -122.27373 & 2000 & 1 & 2014 & 314 \\
\hline & GLK & 46.55750 & -121.61073 & 2000 & 1 & 2014 & 313 \\
\hline & GRCC & 47.31237 & -122.18028 & 2007 & 46 & 2011 & 198 \\
\hline & GSM & 47.20299 & -121.79572 & 2000 & 1 & 2014 & 313 \\
\hline & HSR & 46.17428 & -122.18065 & 2000 & 1 & 2014 & 314 \\
\hline & JUN & 46.14706 & -122.15243 & 2000 & 1 & 2014 & 314 \\
\hline & LMW & 46.66783 & -122.29255 & 2000 & 1 & 2012 & 291 \\
\hline
\end{tabular}




\begin{tabular}{|c|c|c|c|c|c|c|c|}
\hline & LON & 46.75060 & -121.80960 & 2002 & 1 & 2014 & 313 \\
\hline & PCFR & 46.98962 & -122.44218 & 2009 & 365 & 2014 & 315 \\
\hline & PCMD & 46.88896 & -122.30148 & 2000 & 271 & 2013 & 231 \\
\hline & RCM & 46.83564 & -121.73298 & 2000 & 1 & 2014 & 316 \\
\hline & RCS & 46.87083 & -121.73231 & 2000 & 1 & 2014 & 315 \\
\hline & RVN & 47.02722 & -121.33784 & 2000 & 1 & 2002 & 220 \\
\hline & RVW & 46.14794 & -122.74347 & 2000 & 1 & 2014 & 315 \\
\hline & SEP & 46.20021 & -122.19060 & 2000 & 1 & 2004 & 277 \\
\hline & STAR & 46.85085 & -121.79295 & 2010 & 54 & 2014 & 316 \\
\hline & STD & 46.23761 & -122.22396 & 2000 & 1 & 2014 & 316 \\
\hline & STOR & 47.18810 & -121.98880 & 2008 & 337 & 2014 & 316 \\
\hline & SUG & 46.21555 & -122.17626 & 2006 & 297 & 2009 & 217 \\
\hline & TDL & 46.35067 & -122.21704 & 2000 & 1 & 2014 & 316 \\
\hline & WPW & 46.69864 & -121.53734 & 2000 & 1 & 2014 & 315 \\
\hline & YEL & 46.20955 & -122.18899 & 2000 & 1 & 2007 & 258 \\
\hline XD & MH09 & 46.29767 & -121.80103 & 2014 & 175 & 2014 & 273 \\
\hline \multirow[t]{25}{*}{$\mathbf{X U}$} & BD01 & 47.30850 & -121.96990 & 2006 & 365 & 2008 & 258 \\
\hline & BD02 & 47.29770 & -121.96730 & 2007 & 365 & 2008 & 259 \\
\hline & BD03 & 47.30180 & -121.96460 & 2007 & 365 & 2008 & 259 \\
\hline & BD04 & 47.30290 & -121.96100 & 2006 & 365 & 2008 & 259 \\
\hline & BD05 & 47.30650 & -121.95530 & 2006 & 365 & 2008 & 259 \\
\hline & BD11 & 47.30520 & -121.96570 & 2007 & 365 & 2008 & 258 \\
\hline & E050 & 46.76890 & -122.09160 & 2007 & 365 & 2008 & 257 \\
\hline & E060 & 46.62650 & -121.26450 & 2007 & 365 & 2008 & 258 \\
\hline & E070 & 46.50920 & -122.45390 & 2007 & 365 & 2008 & 257 \\
\hline & N070 & 47.05180 & -122.71530 & 2007 & 365 & 2008 & 258 \\
\hline & N080 & 47.16450 & -122.55170 & 2007 & 365 & 2008 & 50 \\
\hline & N085 & 47.06870 & -122.38360 & 2007 & 365 & 2008 & 256 \\
\hline & N090 & 47.18580 & -122.19530 & 2007 & 365 & 2008 & 256 \\
\hline & N100 & 47.29090 & -121.78810 & 2007 & 365 & 2008 & 20 \\
\hline & N110 & 47.14530 & -121.63650 & 2007 & 365 & 2008 & 259 \\
\hline & N120 & 47.21650 & -121.48190 & 2007 & 365 & 2008 & 258 \\
\hline & N130 & 47.24700 & -121.04800 & 2006 & 205 & 2008 & 258 \\
\hline & S050 & 47.00680 & -122.87070 & 2006 & 365 & 2008 & 256 \\
\hline & S055 & 46.83940 & -122.73110 & 2007 & 365 & 2008 & 256 \\
\hline & S060 & 46.99670 & -122.51840 & 2006 & 201 & 2008 & 256 \\
\hline & S065 & 46.86680 & -122.38060 & 2007 & 365 & 2008 & 256 \\
\hline & S070 & 46.98050 & -122.24390 & 2007 & 365 & 2008 & 256 \\
\hline & S080 & 47.00400 & -121.98810 & 2007 & 365 & 2008 & 258 \\
\hline & S090 & 46.98960 & -121.53550 & 2007 & 365 & 2008 & 258 \\
\hline & S100 & 46.98010 & -121.10840 & 2007 & 365 & 2008 & 258 \\
\hline
\end{tabular}




\begin{tabular}{|l|l|l|l|l|l|r|r|}
\hline YB & S01 & 46.21570 & -122.17500 & 2005 & 165 & 2005 & 302 \\
\cline { 2 - 8 } & S02 & 46.20980 & -122.20240 & 2005 & 171 & 2005 & 284 \\
\cline { 2 - 8 } & S03 & 46.19000 & -122.20200 & 2005 & 171 & 2006 & 3 \\
\cline { 2 - 8 } & S04 & 46.18790 & -122.17530 & 2005 & 171 & 2005 & 357 \\
\cline { 2 - 8 } & S05 & 46.23220 & -122.19370 & 2005 & 172 & 2005 & 352 \\
\cline { 2 - 8 } & S06 & 46.16850 & -122.19110 & 2005 & 161 & 2005 & 361 \\
\cline { 2 - 8 } & S07 & 46.19930 & -122.14620 & 2005 & 365 & 2006 & 170 \\
\cline { 2 - 8 } & S08 & 46.22280 & -122.15610 & 2005 & 173 & 2005 & 302 \\
\cline { 2 - 8 } & S09 & 46.22270 & -122.21850 & 2005 & 170 & 2005 & 306 \\
\cline { 2 - 8 } & S10 & 46.17850 & -122.21380 & 2005 & 167 & 2005 & 355 \\
\cline { 2 - 8 } & S11 & 46.16920 & -122.14490 & 2005 & 166 & 2006 & 14 \\
\cline { 2 - 8 } & S12 & 46.23890 & -122.15030 & 2005 & 164 & 2006 & 1 \\
\cline { 2 - 8 } & S13 & 46.20070 & -122.26060 & 2005 & 173 & 2005 & 285 \\
\cline { 2 - 8 } & S14 & 46.14900 & -122.20780 & 2005 & 163 & 2006 & 14 \\
\cline { 2 - 8 } & S15 & 46.18550 & -122.11210 & 2005 & 161 & 2005 & 359 \\
\cline { 2 - 8 } & S16 & 46.22350 & -122.12450 & 2005 & 180 & 2005 & 359 \\
\cline { 2 - 7 } & S17 & 46.20390 & -122.23110 & 2005 & 172 & 2006 & 4 \\
\cline { 2 - 7 } & S19 & 46.21000 & -122.18750 & 2005 & 284 & 2005 & 292 \\
\cline { 2 - 6 } & S20 & 46.19880 & -122.16320 & 2005 & 165 & 2005 & 356 \\
\hline YW & FACD & 46.66190 & -122.85210 & 2007 & 311 & 2010 & 85 \\
\cline { 2 - 6 } & FACF & 46.33160 & -122.77620 & 2007 & 310 & 2010 & 187 \\
\hline ZU & CLEV & 46.84940 & -121.74180 & 2011 & 138 & 2011 & 145 \\
\hline
\end{tabular}




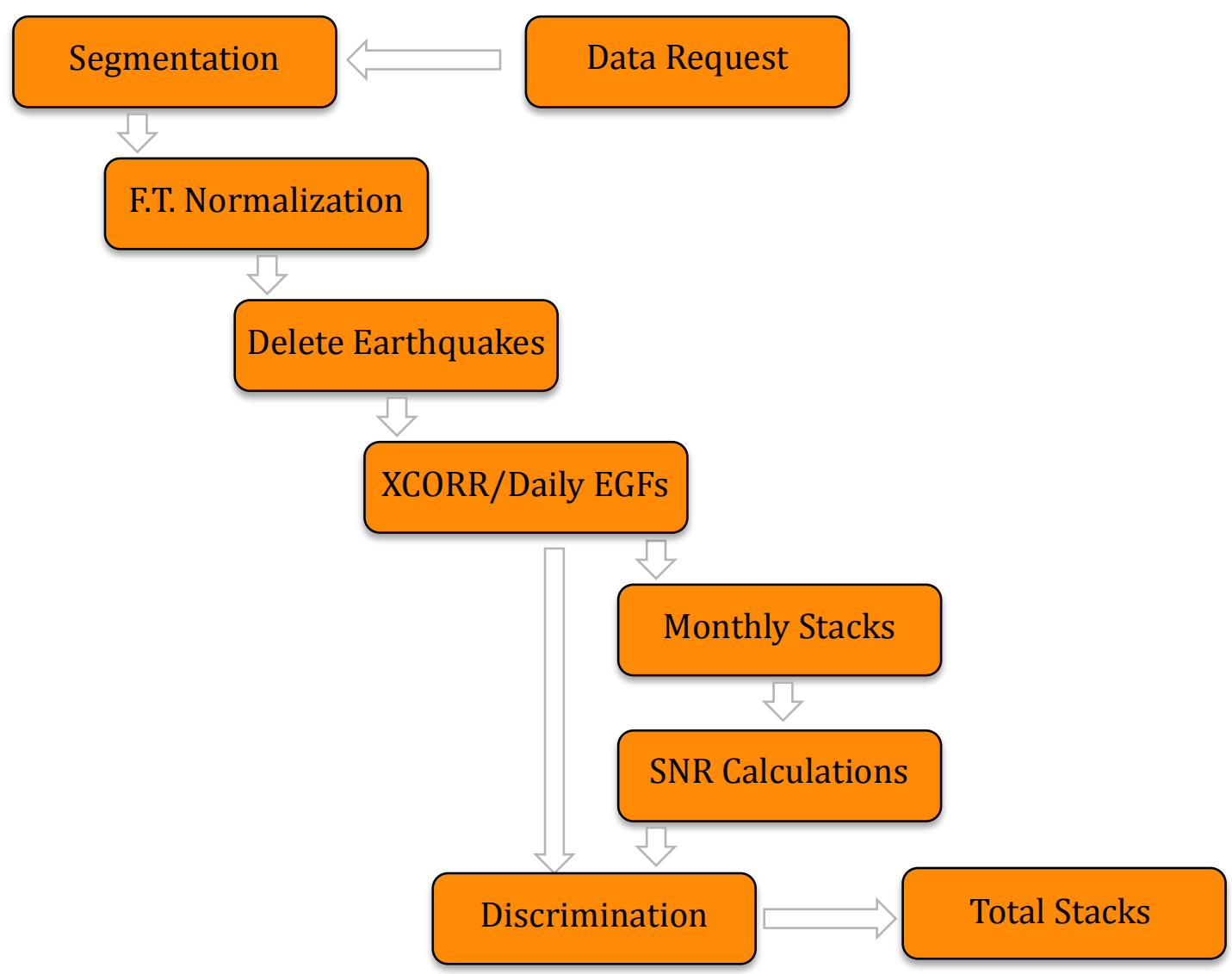

\section{S2.2 Data processing flow-chart.}




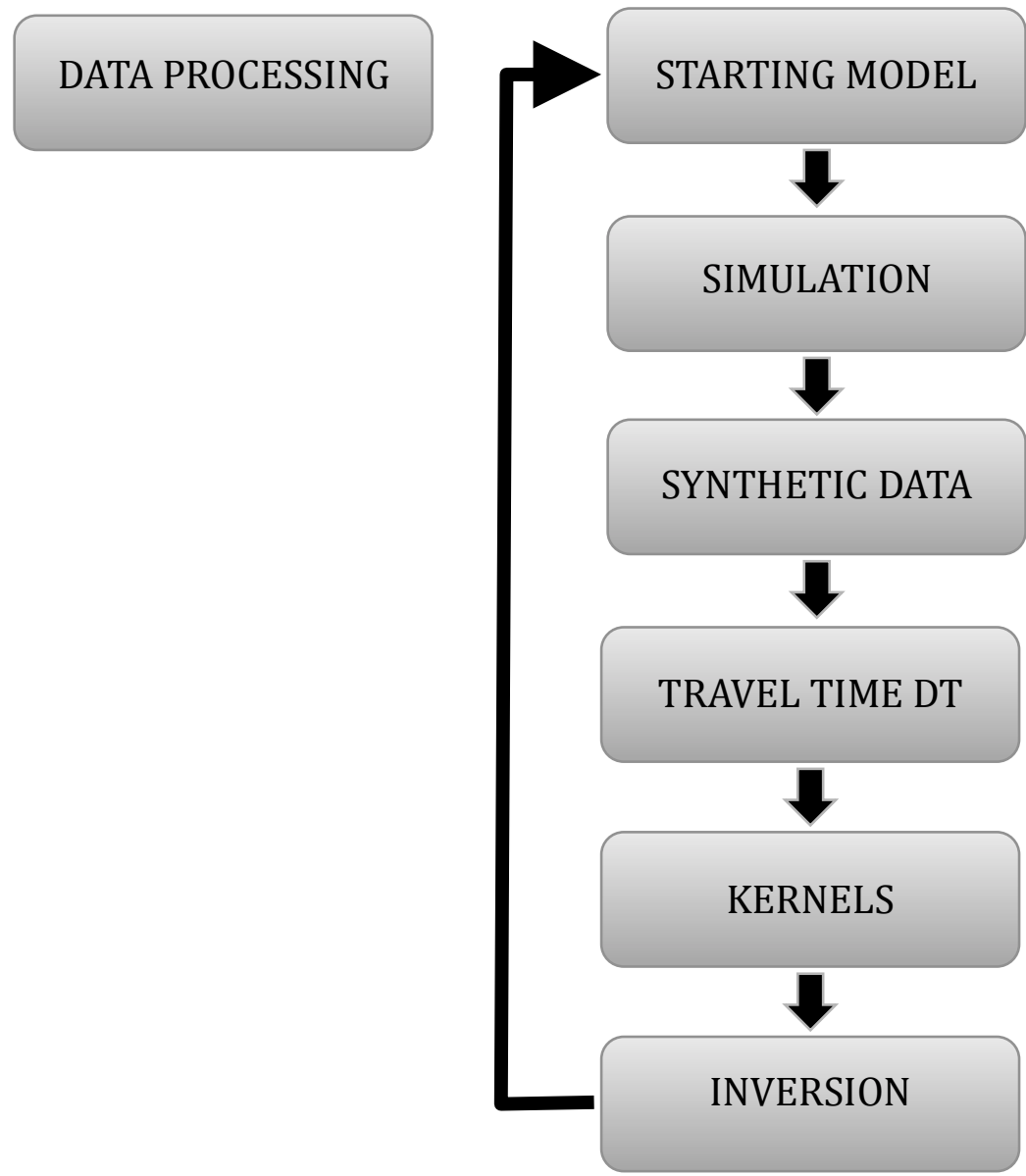

S2.3 | Tomography flow-chart. 


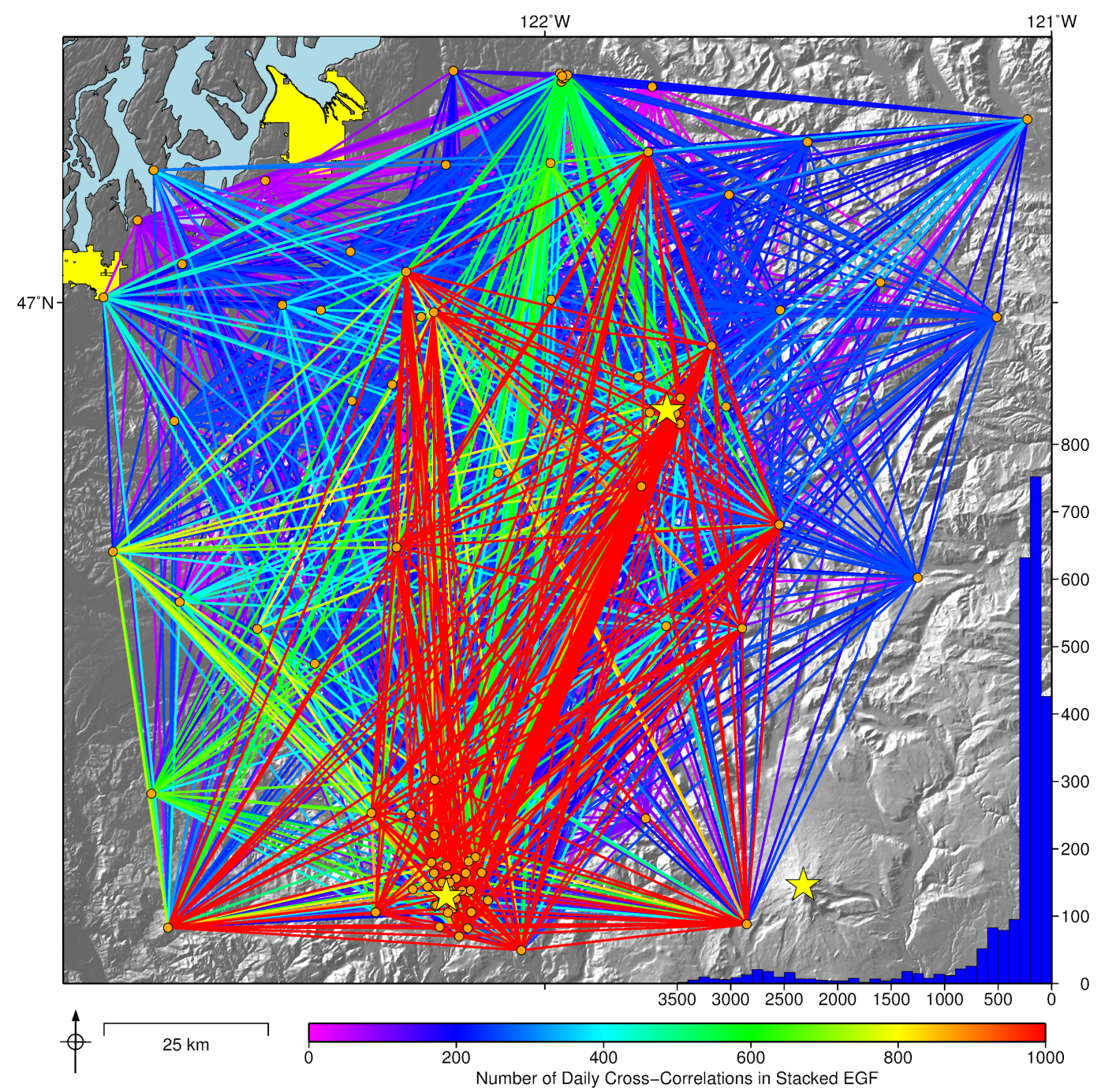

Figure S2.4 | Station locations, ray-paths, and stacked distributions of empirical Green's functions. Seismometer locations (orange circles) relative to volcano locations (yellow-stars). The number of daily cross-correlations in the final stacked empirical Green's function is shown by both the colored ray-path between station locations, and the inset histogram. 

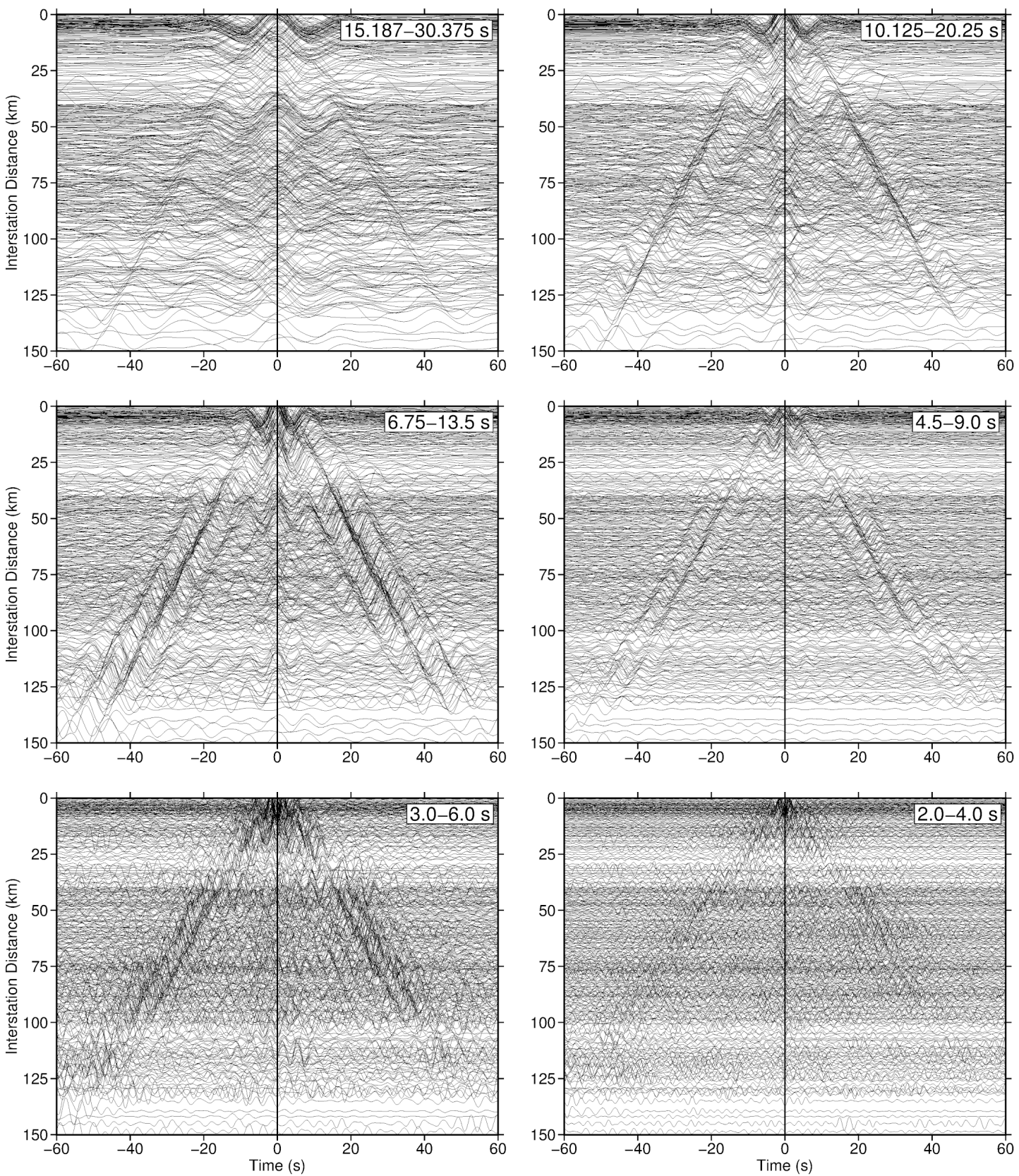

Figure S2.5 | Empirical Green's functions versus distance. The six different frequency bands used in the tomography, showing clear move out of the surface wave arrival. 


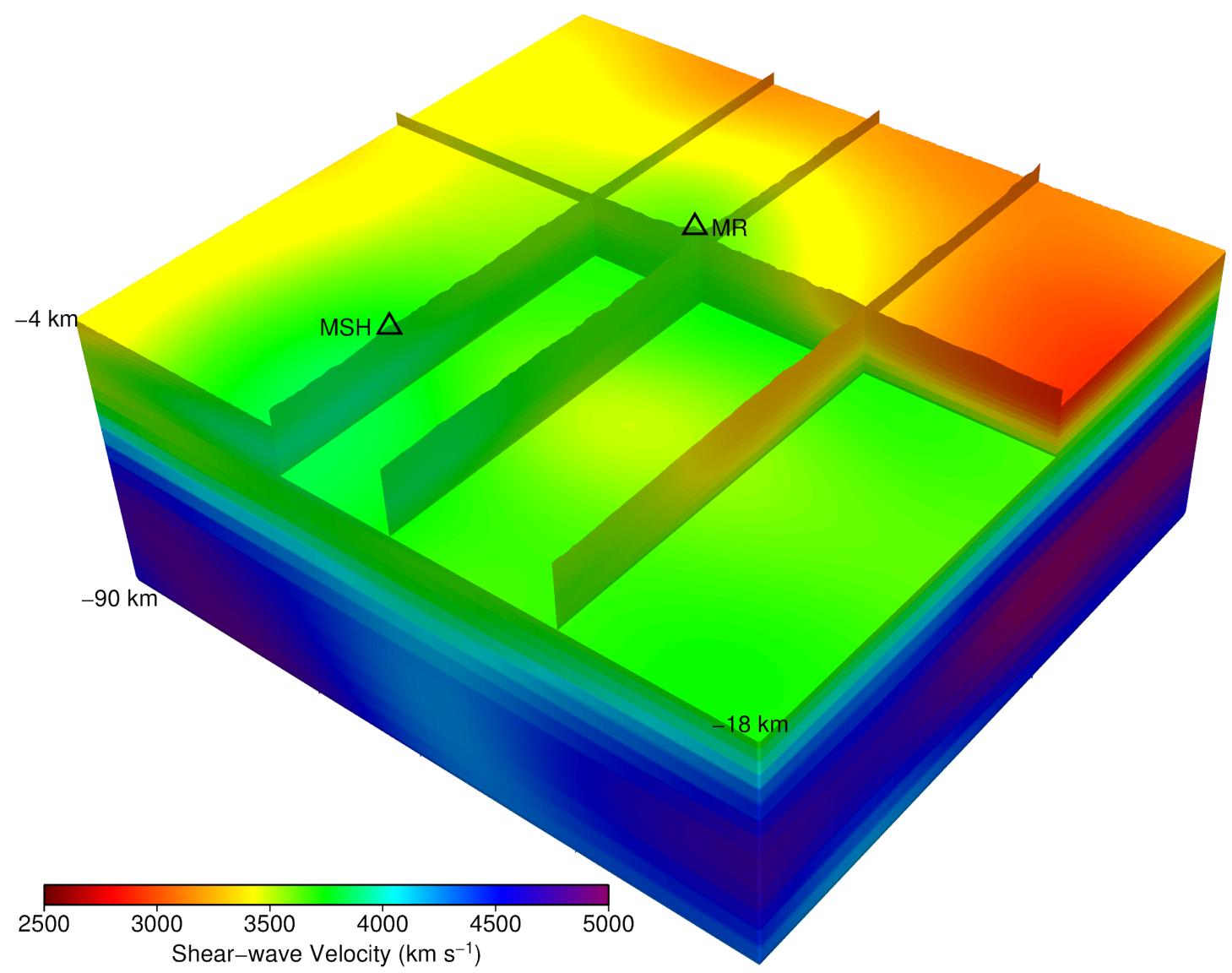

Figure S2.6 | 3D starting model. The starting model for tomography was taken from the regional Gao and Shen (2014) model. While this model resolved some deep-crustal/upper-mantle structure, there was no small-scale structure in the middle-to-upper crust. There was also no noticeable change in the velocity structure from east-to-west characteristic of the border of the Siletzia terrane. A small SWCC anomaly may be observable at $18 \mathrm{~km}$. 


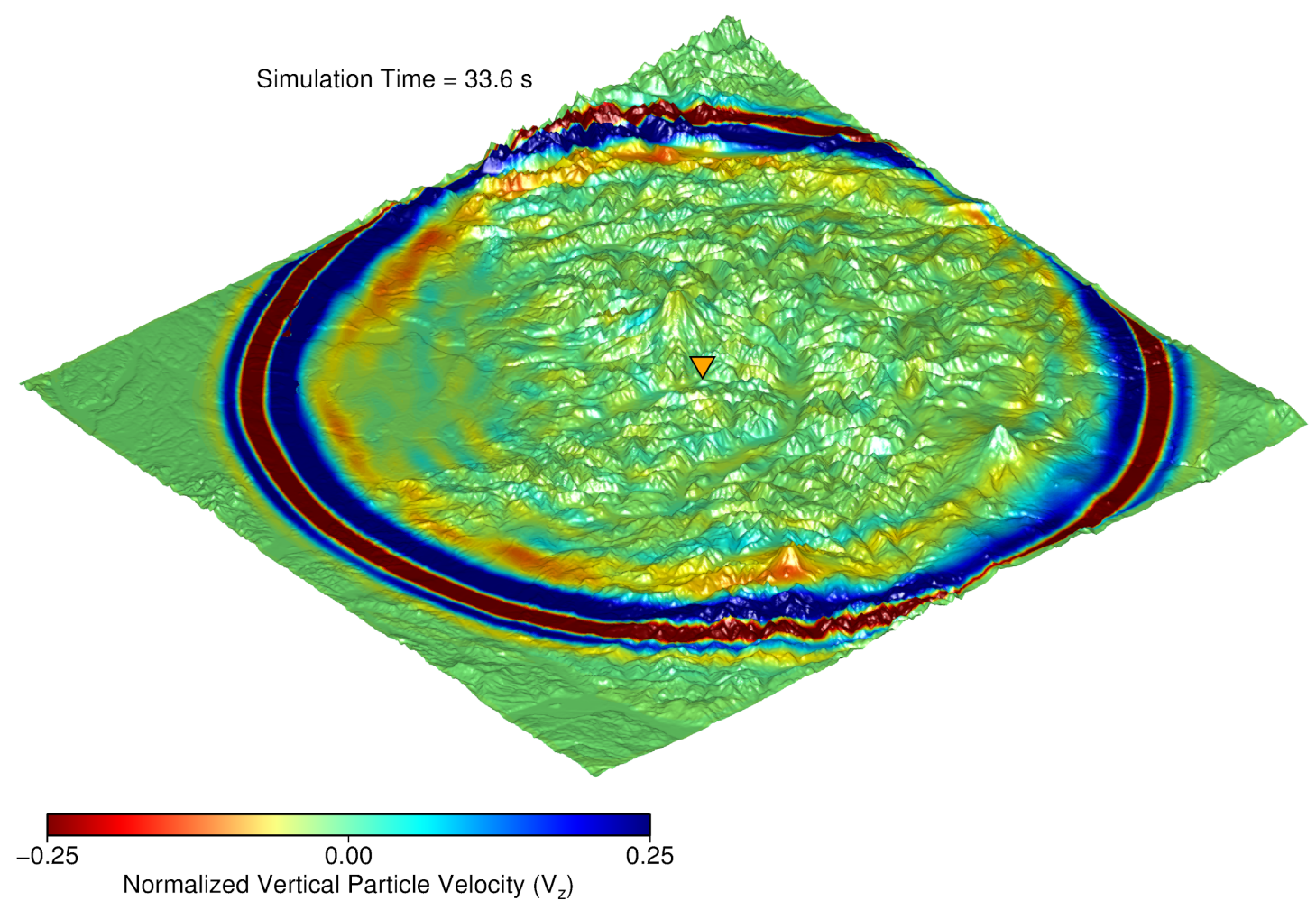

Figure S2.7 | Simulation snapshot. Normalized surface velocity snapshot of wave propagation for station UW.LON (orange inverted triangle), at $\mathrm{t}=33.6 \mathrm{~s}$ relative to source origin time. 

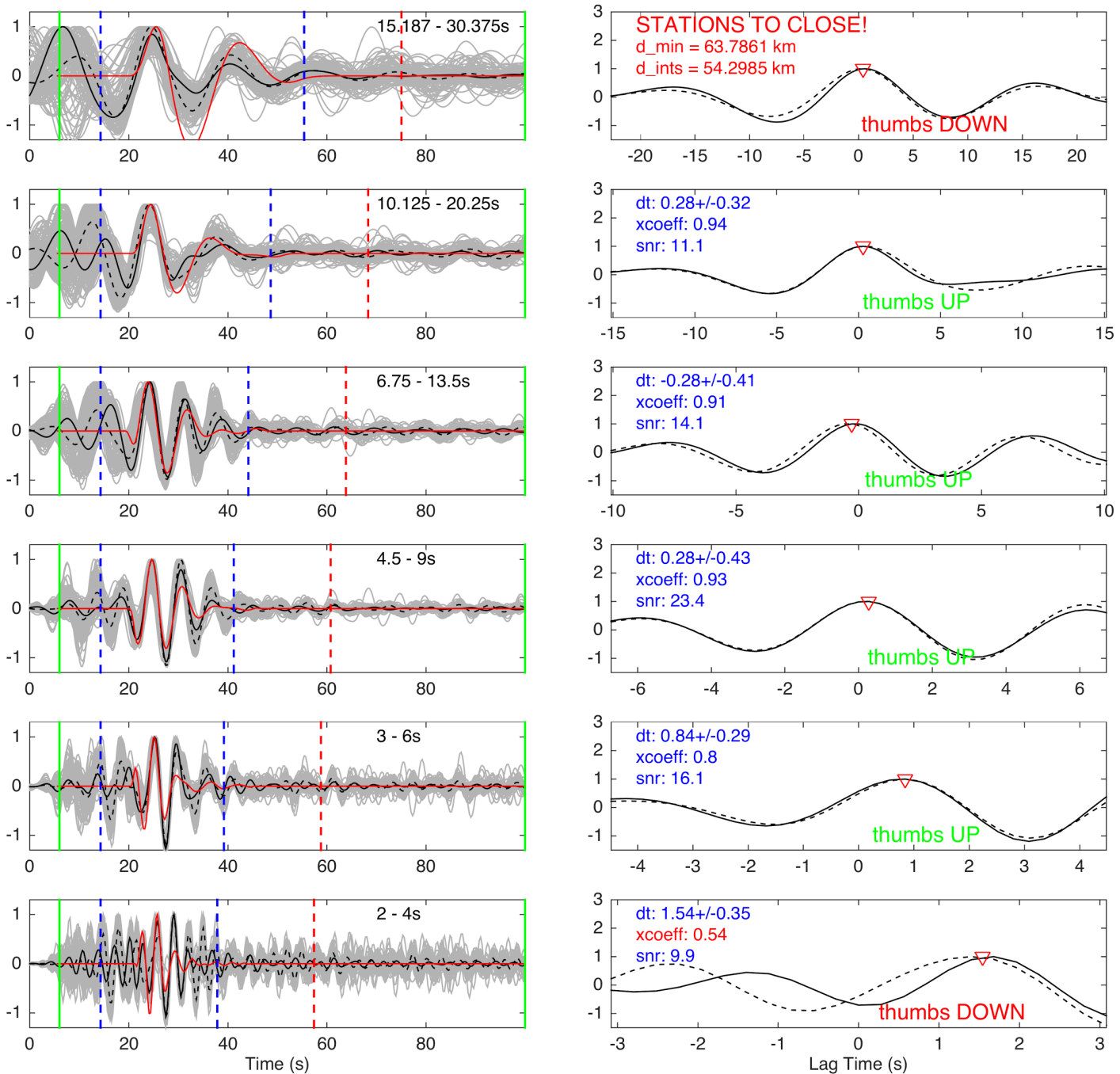

Figure S2.8 | Phase-delay measurment. (left) Time delays are measured between the causal (solid black) and acausal (dashed) portions of the empirical Green's functions (EGFs) and synthetic signal (red). Signal-to-noise values are calculated from period-dependent correlation windows (signal-blue sections; noise-red sections). Uncertainties in the time delay are calculated similarly, but using monthly stacks of EGFs (gray signal). (right) Passed time-delays are subject to numerous constraints including; minimum SNRs/cross-correlation coefficients, maximum time-delays, and minimum interstation distances. 

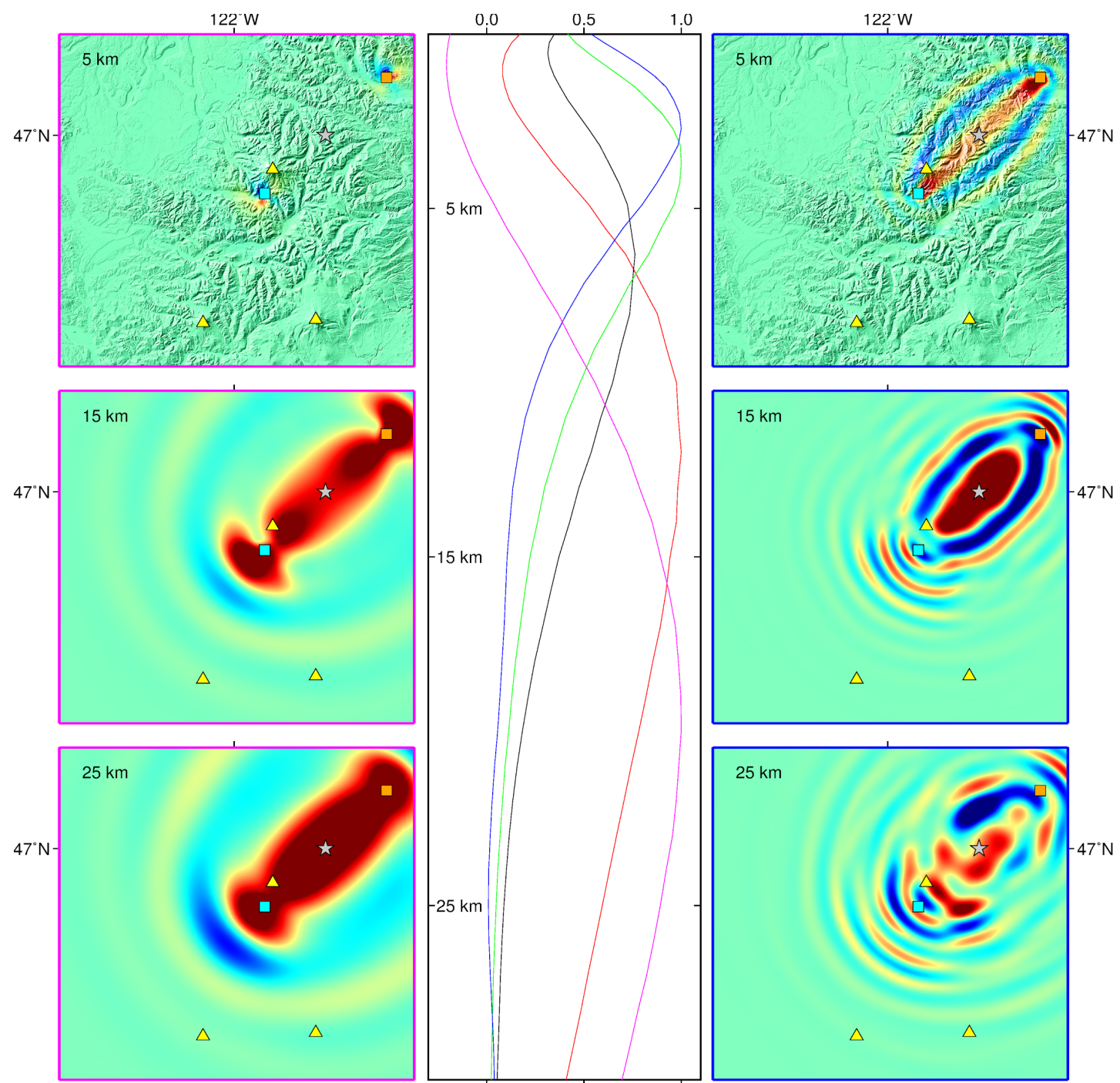

Period Band: $15.187-30.375 \mathrm{~s}$

Normalized $V_{s}$ Phase Kernel
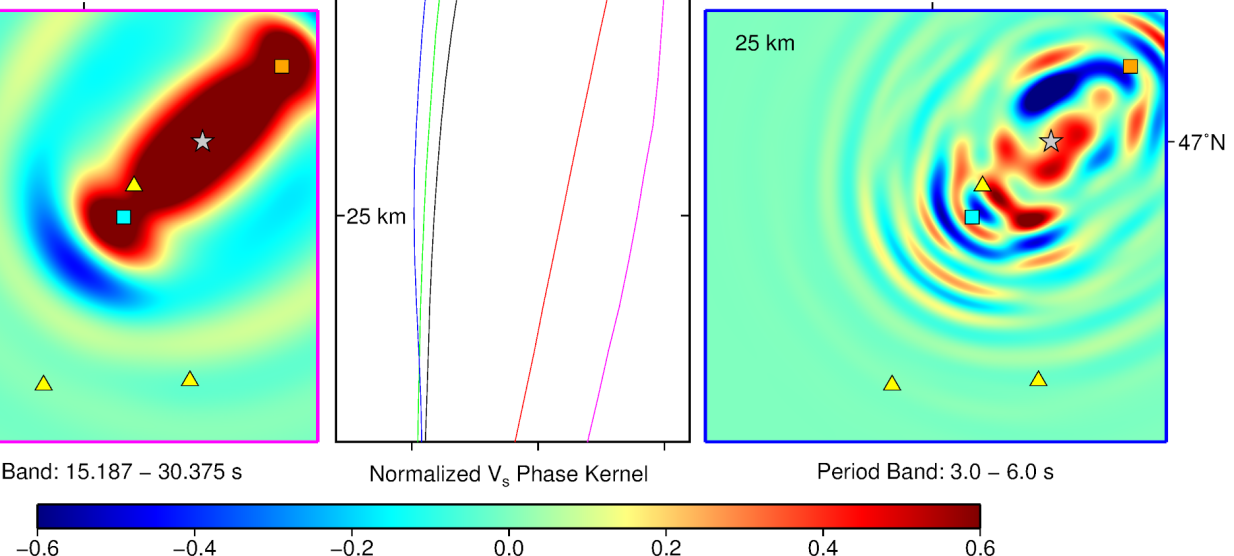

Period Band: $3.0-6.0 \mathrm{~s}$

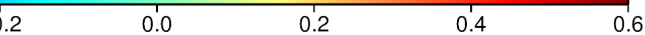

Figure S2.9 | Shear wave velocity phase kernels. (left/right) Sensitivity kernels for two period bands, at three depths, for station-combination UW.LONXU.N130 (blue/orange squares). (inset) Depth versus sensitivity for the five passed frequency bands, at the station-station path midpoint (gray star). Shorter-periods are more sensitive to shallow structure, while long-periods have maximum sensitivity more deep within the model. 

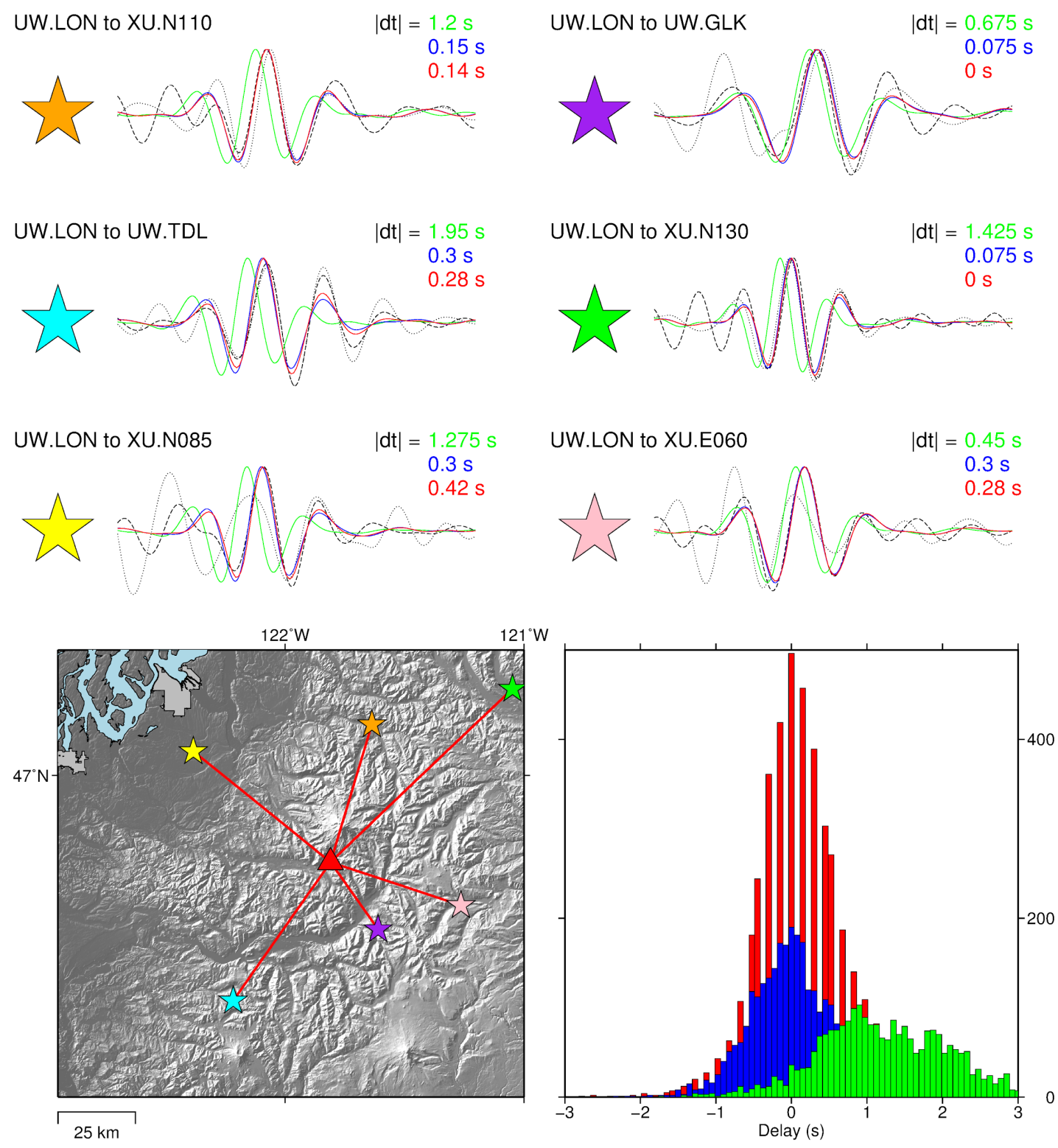

Figure S2.10 | Phase-delay convergence. Frequency-band dependant phasedelays converging on the synthetic signal (causal/acausal, dashed/dotted) shown at three iteration steps; iteration 1 (green), iteration 5 (blue), iteration 10 (red), for six-stations. 

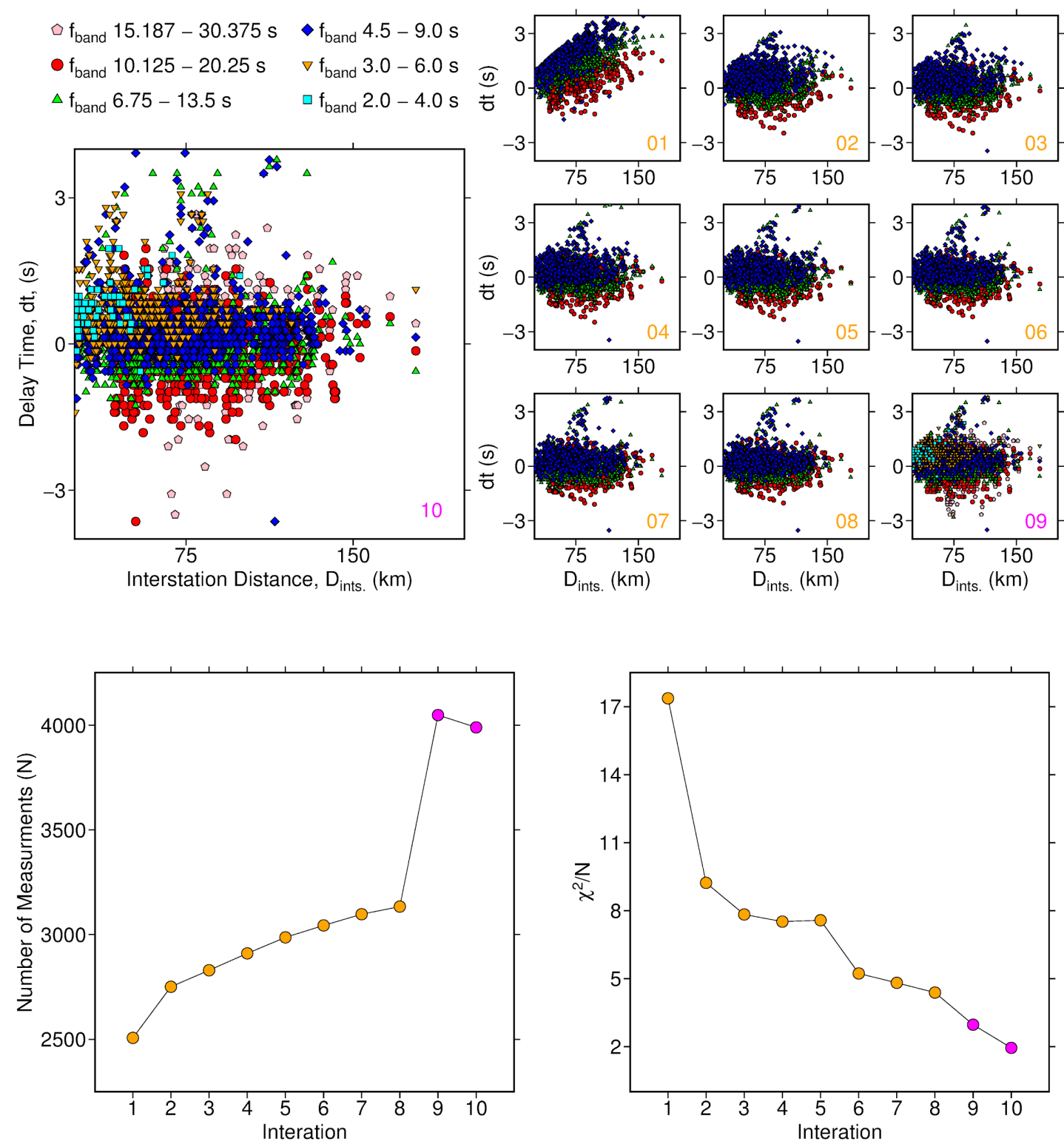

Figure S2.11 | Convergence statistics. (top) Time-delay versus interstation distance for all iteration steps and frequency bands. (bottom-left) The number of passed-measurements slowly increased over each iteration step as the model improved. (bottom right) Similarly, the reduced chi-squared steadily decreased. 

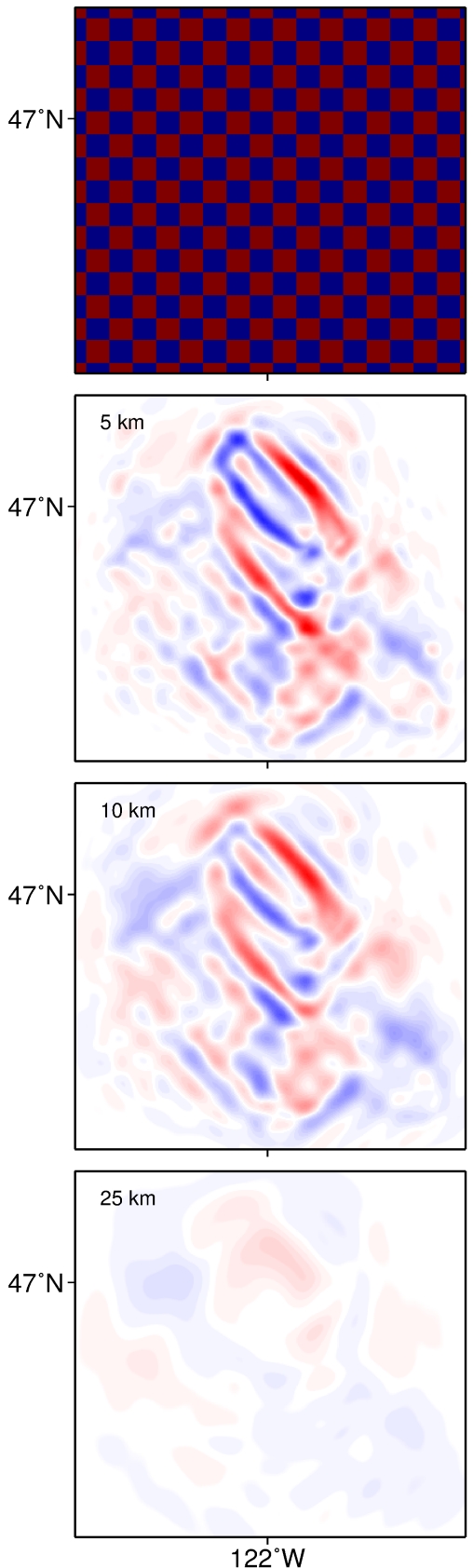

$20 \mathrm{~km}$ cells
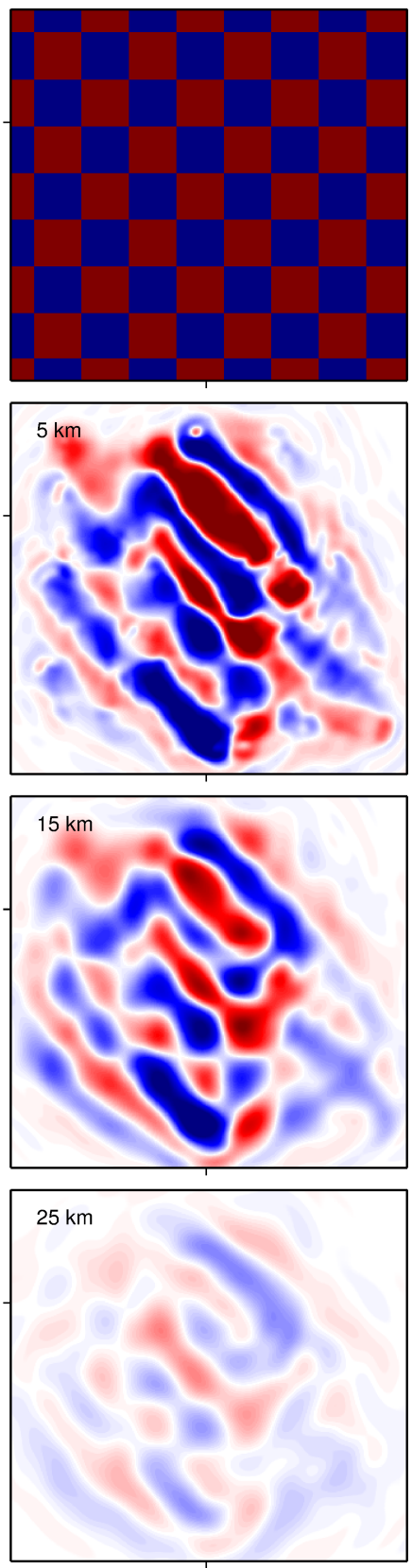

$122^{\circ} \mathrm{W}$
$40 \mathrm{~km}$ cells
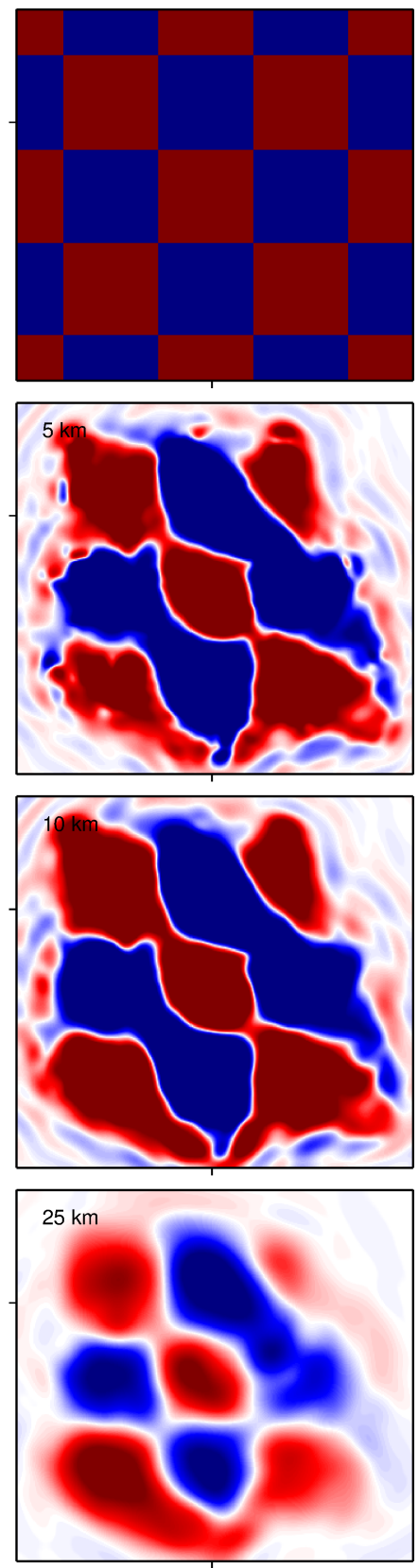

$122^{\circ} \mathrm{W}$

Figure S2.12 | Checkerboard tests. 10, 20, and $40 \mathrm{~km}$ cell-sized checkerboard resolutions tests for the sensitivity kernels of the final iteration (iteration 10). Sensitivity to small-scale structure $(\sim 10 \mathrm{~km})$, is visible to $10 \mathrm{~km}$, but has faded by 25 $\mathrm{km}$. At these depths we can still recover longer wavelength structure, such as the SWCC. 

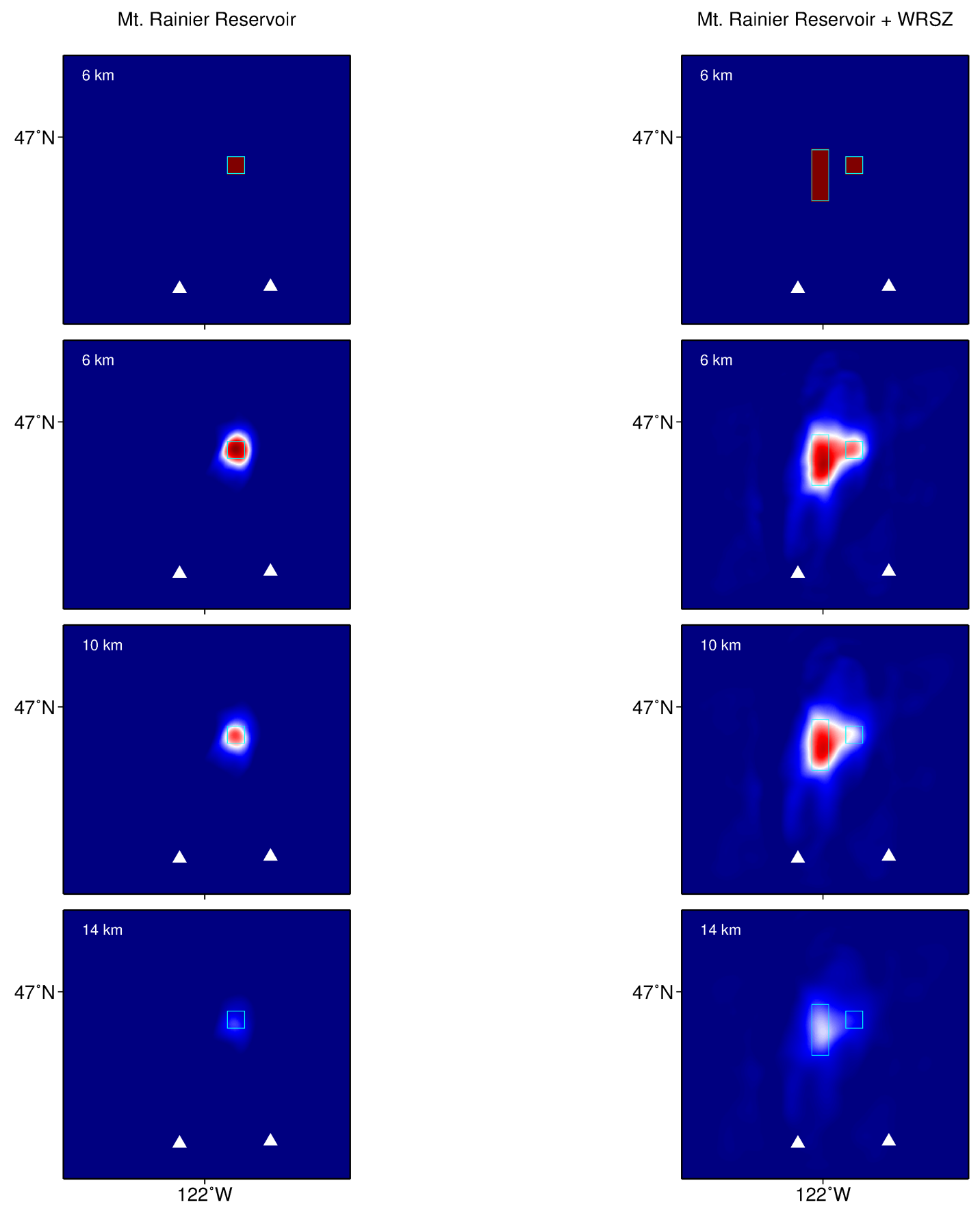

Figure S2.13 | Synthetic tests. Synthetic resolutions tests for the sensitivity kernels of the final iteration (iteration 10), applied to artificial structures representing the Mt. Rainier magma reservoir with and without a neighboring WRSZ reservoir. Smearing is seen between the two reservoirs, indicating we do not have the resolution to comment on their connection from tomography alone. 


\section{BIBLIOGRAPHY}

Annen, C., J. D. Blundy, and R. S. J. Spark (2005), The Genesis of Intermediate and Silicic Magmas in Deep Crustal Hot Zones, J. Petrol., 47, 505-539.

Blackwell, D. D., J. L. Steele, S. Kelley, and M. A. Korosec (1990), Heat flow in the state of Washington and thermal conditions in the Cascade Range, J. Geophys. Res., 95, 19495.

Caricchi, L., L. Burlini, and P. Ulmer (2008), Propagation of P and S-waves in magmas with different crystal contents: Insights into the crystallinity of magmatic reservoirs, J. Volcanol. Geotherm. Res., 178, 740-750.

Christensen, N. I. (1996), Poisson's ratio and crustal seismology, J. Geophys. Res., 101, 3139-3156.

Clague, D. A., and G. B. Dalrymple (1987), The Hawaiian-Emperor volc a nic chain, part I, US Geol. Surv. Prof. Pap. 1350, 5-54.

Crisp, J. A. (1984), Rates of magma emplacement and volcanic output, J. Volcanol. Geotherm. Res., 20, 177-211.

Coombs, M. L., D. A. Clague, G. F. Moore, and B. L. Cousens (2004), Growth and collapse of Waianae Volcano, Hawaii, as revealed by exploration of its submarine flanks, Geochem. Geophys. Geosys., 5(8), 1-30.

Dzurisin, D., R. Y. Koyanagi, and T. T. English (1984), Magma supply and storage at Kilauea volcano, Hawaii, 1956-1983, J. Volcanol. Geotherm. Res., 21(3-4), 177-206. 
Ekström, G., G. A. Abers, and S. C. Webb (2009), Determination of surface-wave phase velocities across USArray from noise and Aki's spectral formulation, Geophys. Res. Lett., 36, L18301-5.

Flinders, A. F., G. Ito, and M. O. Garcia (2010), Gravity anomalies of the Northern Hawaiian Islands: Implications on the shield evolutions of Kauai and Niihau, J. Geo-phys. Res., $115(\mathrm{~B} 8), \mathrm{B} 08412$.

Francis, P., C. Oppenheimer, and D. Stevenson (1993), Endogenous growth of persistently active volcanoes, Nature, 366, 554-557.

Gao, H. and Y. Shen (2014), Upper mantle structure of the Cascades from fullwave ambient noise tomography: Evidence for 3D mantle upwelling in the back-arc, Earth Planet. Sci. Lett., 390, 222-233.

GRAV3D (2007), A program library for forward modeling and inversion of gravity data over 3D structures. Joint/Cooperative Inversion of Geophysical Data, Ver. 3.0, UBC Geophysical Inversion Facility, Univ. British Columbia, Vancouver.

Hammond, P. E. (1998), Tertiary Andesitic Lava-flow Complexes (Stratovolcanoes) in the Southern Cascade Range of WashingtonObservations on Tectonic Processes within the Cascade Arc, Washington Geology, 26(1), 20-30.

Heise, W., H. M. Bibby, T. G. Caldwell, S. C. Bannister, Y. Ogawa, S. Takakura, and T. Uchida (2007), Melt distribution beneath a young continental rift: The Taupo Volcanic Zone, New Zealand, Geophys. Res. Lett., 34, L14313. 
Hildreth, W. (2007), Quaternary magmatism in the Cascades-geologic perspectives, U.S. Geol. Surv. Prof. Pap., 1744.

Hill, G. J., T. G. Caldwell, W. Heise, D. G. Chertkoff, H. M. Bibby, M. K. Burgess, J. P. Cull and R. A. F. Cas (2009), Distribution of melt beneath Mount St Helens and Mount Adams inferred from magnetotelluric data, Nat. Geosci., 2, 785-789.

Hooft, E. E., and R. S. Detrick (1993), The role of density in the accumulation of basaltic metls at mid-ocean ridges, Geophys. Res. Lett., 20 (6), 423-426.

Kauahikaua, J., T. Hildenbrand, and M. Webring (2000), Deep magmatic structures of Hawaiian volcanoes, imaged by three-dimensional gravity models, Geology, 28(10), 883-886.

Kern, H. and A. Richter (1981), Temperature derivatives of compressional and shear wave velocities in crustal and mantle rocks at 6 kbar confining pressure, J. Geophys., 49, 47-56.

Koulakov, I., E. I. Gordeev, N. L. Dobretsov, V. A. Vernikovsky, S. Senyukov, and A. Jakovlev (2011), Feeding volcanoes of the Kluchevskoy group from the results of local earthquake tomography, Geophys. Res. Lett., 38, L09305.

Lees, J. M. and R. S. Crosson (1989), Tomographic inversion for threedimensional velocity structure at Mount St. Helens using earthquake data, J. Geophys. Res., 94, 5716.

Lees, J. M. and R. S. Crosson (1990), Tomographic imaging of local earthquake delay times for three-dimensional velocity variation in western Washington, J. Geophys. Res., 95, 4763. 
Li, Y., and D. W. Oldenburg (1998), 3-D inversion of gravity data, Geophysics, $63,109-119$.

Lin, G., F. Amelung, Y. Lavallee, and P. G. Okubo (2014), Seismic evidence for a crustal magma reservoir beneath the upper east rift zone of Kilauea volcano, Hawaii, Geology, 42, 187-190.

Macdonald, G. A., A. T. Abbott, and D. C. Cox (1983), Volcanoes in the Sea: Honolulu, Univ. Hawaii Press, 517.

Maceira, M., C. Larmat, and R. W. Porritt (2015), On the validation of seismic imaging methods: Finite frequency or ray theory? Geophys. Res. Lett., 42, 323330.

Mastin, L. G., M. Lisowski, E. Roeloffs, and N. Beeler (2009), Improved constraints on the estimated size and volatile content of the Mount St. Helens magma system from the 2004-2008 history of dome growth and deformation, Geophys. Res. Lett., 36, L20304.

Marschall, H. R. and J. C. Schumacher (2012), Arc magmas sourced from mélange diapirs in subduction zones, Nat. Geosci., 5, 862-867.

Mattinson, J. M. (1977), Emplacement history of the Tatoosh volcanic-plutonic complex, Washington: Ages of zircons, Geol. Soc. Am. Bull.

McCrory, P. A., J. L. Blair, D. H. Oppenheimer, and A. S. R. Walter (2006), Depth to the Juan de Fuca Slab Beneath the Cascadia Subduction Margin-A 3-D Model for Sorting Earthquakes, USGS Data Series, 91, 1-13. 
McGary, R. S., R. L. Evans, P. E. Wannamaker, J. Elsenbeck, and S. Rondenay (2014), Pathway from subducting slab to surface for melt and fluids beneath Mount Rainier, Nature, 511, 338-340.

Moore, J. G., D. A. Clague, R. T. Holcomb, P. W. Lipman, W. R. Normark, and M. E. Torresan (1989), Prodigious submarine landslides on the Hawaiian Ridge, J. Volcanol. Geotherm. Res., 94 (B12), 17465-17484.

Moore, J.G. (2001), Density of basalt core from Hilo drill hole, Hawaii, J. Volcanol.Geotherm. Res., 112 (1-4), 221-230.

Moran, S. C., J. M. Lees, and S. D. Malone (1999), Pwave crustal velocity structure in the greater Mount Rainier area from local earthquake tomography, $J$. Geophys. Res., 104, 10775-10786.

Obrebski, M., G. A. Abers, and A. Foster (2015), Magmatic arc structure around Mount Rainier, WA, from the joint inversion of receiver functions and surface wave dispersion, Geochem. Geophys. Geosyst., 16, 178-194.

Okubo, P. G., H. M. Benz, and B. A. Chouet (1997), Imaging the crustal magma sources beneath Mauna Loa and Kilauea Volcanoes, Hawaii, Geology, 25(10), 867-870.

Park, J., J. K. Morgan, C. A. Zelt, and P. G. Okubo, (2009), Volcano-tectonic implications of 3-D velocity structures derived from joint active and passive source tomography of the island of Hawaii, J. Geophys. Res., 114 (B9), B09301.

Paulatto, M., C. Annen, T. J. Henstock, E. Kiddle, T. A. Minshull, R. S. J. Sparks, and B. Voight (2012). Magma chamber properties from integrated seismic 
tomography and thermal modeling at Montserrat, Geochem. Geophys. Geosyst., $13,1-18$.

Robinson, J. E., and B. W. Eakins (2006), Calculated volumes of individual shield vol- canoes at the young end of the Hawaiian Ridge, J. Volcanol. Geotherm. Res., 151, 309-317.

Sinton, J. M., D. Eason, M. Tardona, D. Pyle, I. van der Zander, H. Guillou, A. Flinders, D. Clague, and J. Mahoney (2013), Kaena Volcano a precursor volcano of the island of Oahu, Hawaii, Geo. Soc. Amer. Bull., submitted.

Sisson, T. W., V. J. M Salters, and P. B. Larson (2013), Petrogenesis of Mount Rainier andesite: Magma flux and geologic controls on the contrasting differentiation styles at stratovolcanoes of the southern Washington Cascades, Geol. Soc. Am. Bull., 126, 122-144.

Stanley, W. D., C. Finn, and J. L Plesha (1987), Tectonics and conductivity structures in the Southern Washington Cascades, J. Geophys. Res., 92, 10179.

Strange, W. E., G. P. Woollard, and J. C. Rose (1965), An analysis of the gravity field over the Hawaiian Islands in terms of crustal structure, Pac. Sci., 19(3), 381-389.

Tuffen, H., R. Smith, and P. R. Sammonds (2008), Evidence for seismogenic fracture of silicic magma, Nature, 453, 511-514.

Venezky, D. Y. and M. J. Rutherford (1997), Preeruption conditions and timing of dacite-andesite magma mixing in the 2.2 ka eruption at Mount Rainier, $J$. Geophys. Res., 102, 20069-20086. 
Wagner, D., I. Koulakov, W. Rabbel, B. G. Luehr, A. Wittwer, H. Kopp, M. Bohm, G. Asch and the MERAMEX Scientists (2007), Joint inversion of active and passive seismic data in Central Java, Geophys. J. Int., 170, 923-932.

Walker, G. P. (1986), Koolau dike complex, Oahu: intensity and origin of a sheeted-dike complex high in a Hawaiian volcanic edifice, Geology, 14 (4), 310-313.

Wannamaker, P. E., R. L. Evans, P. A. Bedrosian, M. J. Unsworth, V. Maris, and R. S. McGary (2014), Segmentation of plate coupling, fate of subduction fluids, and modes of arc magmatism in Cascadia, inferred from magnetotelluric resistivity. Geochem. Geophys. Geosyst., 15, 4230-4253.

Watts, A.B., and J. R. Cochran (1974), Gravity anomalies and flexure of the lithosphere along the Hawaiian-Emperor seamount chain, Geophys. J. Royal Astr. Soc., 38(1), 119-141.

Watts, A. B., U. S. ten Brink, P. Buhl, and T. M. Brocher (1985), A multichannel seismic study of lithospheric flexure across the HawaiianEmperor seamount chain, Nature, 315, 105-111.

Wessel, P., and W. H. F. Smith (1991), Free software helps map and display data, Eos Trans. AGU, 72 (41), 441, 445-446.

White, S. M., J. A. Crisp, and F. J. Spera (2006), Long-term volumetric eruption rates and magma budgets, Geochem. Geophys. Geosys., 7 (3), 1-20.

Wohletz, K. H. (1999), MAGMA: Calculates IUGS volcanic rock classification, densities, and viscosities. Los Alamos National Laboratory computer code LA-CC 99-28, Los Alamos New Mexico. 
Zhang, Z. and Y. Shen (2008), Cross-dependence of finite-frequency compressional waveforms to shear seismic wave speeds, Geophys. J. Int., 174, 941-948.

Zhang, W. and Y. Shen (2010), Unsplit complex frequency-shifted PML implementation using auxiliary differential equations for seismic wave modeling, Geophysics, 75, T141-T154.

Zhang, W., Z. Zhang, and X. Chen (2012), Three-dimensional elastic wave numerical modelling in the presence of surface topography by a collocatedgrid finite-difference method on curvilinear grids, Geophys. J. Int., 190, 358378.

Zhao, L., T. H. Jordan, K. B. Olsen, and P. Chen (2005), Frechet Kernels for Imaging Regional Earth Structure Based on Three-Dimensional Reference Models, Seismol. Soc. Am. Bull., 95, 2066-2080. 